\title{
Geochemical constraints on the evolution of mafic and felsic rocks in the Bathani volcanic and volcano- sedimentary sequence of Chotanagpur Granite Gneiss Complex
}

\author{
Ashima Saikia $^{1, *}$, Bibhuti Gogoi ${ }^{1}$, Mansoor Ahmad $^{2}$ and Talat Ahmad ${ }^{1}$ \\ ${ }^{1}$ Chatra Marg, Department of Geology, University of Delhi, Delhi 110 00\%, India. \\ ${ }^{2}$ Rajabazar, Patna 800 020, India. \\ *Corresponding author. e-mail: ashima.saikia@gmail.com
}

The Bathani volcanic and volcano-sedimentary (BVS) sequence is a volcanic and volcano-sedimentary sequence, best exposed near Bathani village in Gaya district of Bihar. It is located in the northern fringe of the Chotanagpur Granite Gneiss Complex (CGGC). The volcano-sedimentary unit comprises of garnet-mica schist, rhyolite, tuff, banded iron formation (BIF) and chert bands with carbonate rocks as enclaves within the rhyolite and the differentiated volcanic sequence comprises of rhyolite, andesite, pillow basalt, massive basalt, tuff and mafic pyroclasts. Emplacement of diverse felsic and mafic rocks together testifies for a multi-stage and multi-source magmatism for the area. The presence of pillow basalt marks the eruption of these rocks in a subaqueous environment. Intermittent eruption of mafic and felsic magmas resulted in the formation of rhyolite, mafic pyroclasts, and tuff. Mixing and mingling of the felsic and mafic magmas resulted in the hybrid rock andesite. Granites are emplaced later, crosscutting the volcanic sequence and are probably products of fractional crystallization of basaltic magma. The present work characterizes the geochemical characteristics of the magmatic rocks comprising of basalt, andesite, rhyolite, tuff, and granite of the area. Tholeiitic trend for basalt and calc-alkaline affinities of andesite, rhyolite and granite is consistent with their generation in an island arc, subduction related setting. The rocks of the BVS sequence probably mark the collision of the northern and southern Indian blocks during Proterozoic period. The explosive submarine volcanism may be related to culmination of the collision of the aforementioned blocks during the Neoproterozoic (1.0 Ga) as the Grenvillian metamorphism is well established in various parts of CGGC.

\section{Introduction}

The Chotanagpur Granite Gneiss Complex (CGGC), a high grade terrain in the eastern part of the Central Indian Tectonic Zone (CITZ), covers an area of $80,000 \mathrm{~km}^{2}$ having a ENE-WSW trend. It consists predominantly of amphibolite to granulite facies rocks juxtaposed between two low grade mobile belts, namely the North Singhbhum mobile belt in the south and the Mahakoshal mobile belt in the north (figure 1). The evolution of CGGC has been marked by multiple episodes of magmatism, metamorphism and deformation over a geological history spanning from Proterozoic till about $65 \mathrm{Ma}$ (Mukherjee and Ghose 1998). Several attempts were made to classify

Keywords. Chotanagpur Granite Gneiss Complex (CGGC); Munger-Rajgir belt; Bathani volcanic and volcano-sedimentary (BVS) sequence; volcanic arc; subduction; magma mixing. 


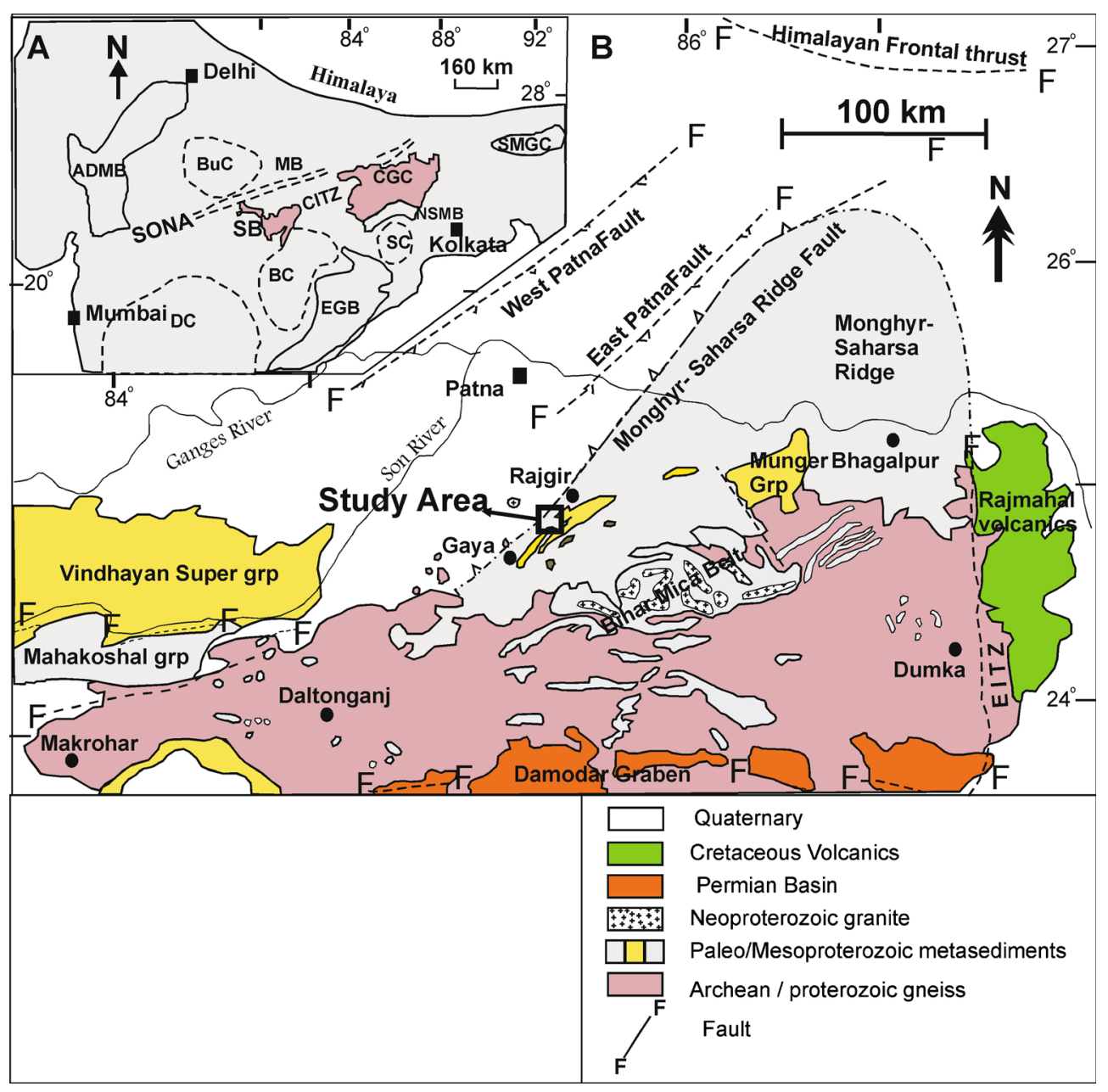

Figure 1. Geological map of the Chotanagpur Granite Gneiss Complex (CGGC) and adjoining areas after GSI 1998 (reproduced after Chatterjee and Ghosh 2011). The tectonic features are marked after Sastri et al. (1971), Rao (1973), Valdiya (1976), GSI (2000) and Chatterjee et al. (2010). Marked in the map in black open square is the study area of present work. In the inset is the map of India showing the relative position of CGGC with respect to various Proterzoic complexes of the Indian shield. Abbreviations. ADMB: Aravalli-Delhi Mobile Belt, BuC: Bundelkhand Craton, BC: Bastar Craton, CGC: Chotanagpur Gneissic Complex, CITZ: Central Indian Tectonic Zone, DC: Dharwar Craton, EGB: Eastern Ghats Belt, EITZ: Eastern Indian Tectonic Zone, grp: Group, MB: Mahakoshal Belt, NSMB: North Singhbhum Mobile Belt, SB: Satpura Belt, SC: Singhbhum Craton, SMGC: Shillong-Meghalaya Gneissic Complex, SONA: Son-Narmada Graben.

the CGGC by various researchers. Ghose (1983) and Banerji (1991) have based their classification on lithostratigraphic units, viz., crystalline basement, older metasediments, and later intrusives associated with the Chotanagpur, Satpura, and Munger orogenic phases. Singh (1998) classified the CGGC based on lithodemic groups and placed the CGGC lithodemic group as the oldest followed by the Kodarma Group and the Rajgir Group. Mahadevan (2002) classified the CGGC into five east-west divisions based on the Damodar and the Koel river Gondwana basins as reference frames. However, Sanyal and Sengupta (2012) have argued that geological information is too less from this terrain to attempt any robust classification of CGGC.
Available radiometric age dates obtained by various methods like $\mathrm{U}-\mathrm{Pb}$ zircon, whole rock $\mathrm{Rb}-\mathrm{Sr}$, $\mathrm{K}-\mathrm{Ar}$, and monazite chemical dates have been used to infer four magmato-metamorphic events, viz., $>2.5,1.6-1.5,1.2-1.0$, and $0.9 \mathrm{Ga}$ in this crustal block (Chatterjee et al. 2008; Maji et al. 2008; Singh and Krishna 2009; Chatterjee et al. 2010; Karmakar et al. 2011; Mukhopadhyay et al. 2011 and references therein; Sanyal and Sengupta 2012). Most of these ages are from the metamorphosed basement lithology of the eastern part of the high grade terrain. The protolith of the high grade metamorphic rocks for this terrain which were part of the proto-crust are difficult to recognize following multiple metamorphic episodes. Thus, the evolutionary history of CGGC has remained speculative 
to build a meaningful stratigraphy due to absence of lithological, structural, petrological and precise geochronological constraints from various basins of the terrain.

We present new geochemical, petrological and mineral chemical data for the volcanic and volcanosedimentary sequence in juxtaposition with Rajgir metasediments best exposed near Bathani village in the Gaya district of Bihar (Ahmad and Wanjari 2009; Ahmad and Dubey 2011) located on the northern fringe of the CGGC.

The exposed areas at the northern margin of CGGC comprise of the Bihar Mica Belt (BMB), Munger Group, and the Rajgir-Gaya sub-basins. The BMB has a basement cover relationship with the CGGC as is evident from the occurrence of Inderwa Conglomerate (Mukherjee and Ghose 1998; Ghose and Mukherjee 2000). The Munger Group and the Rajgir-Gaya metasediments comprise of folded phyllite-quartzite sequence with sporadic occurrences of mafic-ultramafic and granitic intrusives (Das 1967; Mazumdar 1988). Based on their lithological and structural similarities, these metasediments have been correlated with the folded synclinal sequences of the Son-Narmada Valley (Das 1967).

The Bathani volcanic and volcano-sedimentary sequence (BVS sequence) occurring within the graben is flanked by CGGC to the south and flat alluvial country with occasional granitic inselberg to the north. A fault trending north-east along the eastern boundary of the Rajgir-Gaya basin (Das 1967; Srivastava and Sengupta 1967) hsas been correlated with the NE-SW Monghyr-Saharsa Ridge Fault (MSRF) on the northwestern edge of the CGGC (Sastri et al. 1971; Rao 1973; Valdiya 1976; Raiverman et al. 1983; Goswami et al. 2009). Bouger gravity anomaly map (Das and Patel 1984) shows anomalous NE-SW trending gravity high to the north of Bodh Gaya suggesting the probability of the presence of a regional fault (continuation of Son-Narmada Lineament) along with intrusive basic igneous material beneath. The plutonic rocks reported from the northwestern side of MSRF in association with schists, phyllites, quartzite have been correlated with the Mahakoshal Group of the Son-Narmada graben (Chatterjee and Ghosh 2011).

Reported occurrence of the BVS sequence by Ahmad and Wanjari (2009) and Ahmad and Dubey (2011) presents the Munger-Rajgir belt in an entirely novel lithostratigraphic perspective. Extensive magmatic activity in the area has been established beyond doubt. It is important to understand how and under which tectonic regime this magmatic activity took place. Constraining the geochemical signatures of BVS sequence will add to our understanding of Proterozoic magmatism in the eastern Indian shield.

\section{Geological background}

The BVS sequence is extended over known $\sim 40 \mathrm{~km}$ aerial distance from Bathani $\left(24^{\circ} 59.5^{\prime} \mathrm{N}\right.$, $85^{\circ} 16^{\prime} \mathrm{E}$ ), Gaya District (Toposheet $72 \mathrm{H} / 5$ ) to

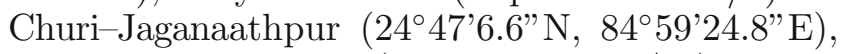
Gaya District, Bihar (Toposheet $72 \mathrm{D} / 13$ ) on the northern fringe of CGGC. Three litho-domains have been discerned so far for the Munger-Rajgir belt based on field relationship, viz., (a) granitoids with occurrences of xenoliths of anorthosite and mafic rocks like gabbro and hornblendite, (b) the volcanic and volcano sedimentary sequence exposed in Bathani village (BVS) and to the south of it is the (c) Rajgir metasediments (figure 2).

The volcano-sedimentary unit comprises of garnet-mica schist, rhyolite, tuff, banded iron formation (BIF) and chert bands with carbonate rocks as enclaves within the rhyolite unit whereas the differentiated volcanic sequence comprises of rhyolite-andesite (figure $3 \mathrm{a}, \mathrm{b}$ ), pillow basalt (figure 3c), massive basalt (figure 3d), tuff (figure 3e) and mafic pyroclasts. There is no remarkable break between the two sequences but on the basis of primary sedimentary and volcanic structures it may be established that the volcano-sedimentary sequence is overlain by the differentiated volcanic sequence. The Mesoproterozoic Rajgir metasediments comprise stratigraphically of two distinct quartzite horizons underlain and overlain by phyllites. Volcano-sedimentary sequences as well as the lower unit of Rajgir metasediments are intruded persistently by concordant ultramafic bodies of gabbro-pyroxenite suite. However, only few ultramafics are exposed in antiformal valley portion formed as a consequence of the second phase of deformation, but subsurface probe in the area revealed that various concordant ultramafic intrusions of variable thickness are present (personal communication). Granitic bodies (figure 3f) are seen at places overlying or cross cutting these units suggesting a late stage felsic magmatic activity in the area. Ahmad and Wanjari (2009) suggested bimodal volcanism in the area based on the occurrence of felsic volcanic rhyolite and mafic pillow basalt. The thrust contact between the overlaying volcano-sediments and granitoids with underlying rhyolite of differentiated volcanics at MirazapurGere, suggests that the rocks of the area had experienced large scale brittle deformation (Ahmad and Paul 2013).

Mixing and mingling of mafic and felsic magmas is collaborated by the presence of felsic clasts within mafic ground mass (figure $4 \mathrm{a}$ ), rapakivi feldspars in andesite (figure 4b), hybrid zones at mafic and felsic flow contacts resulting in andesite (figure 4c), felsic ocelli in mafics (figure 4d), 


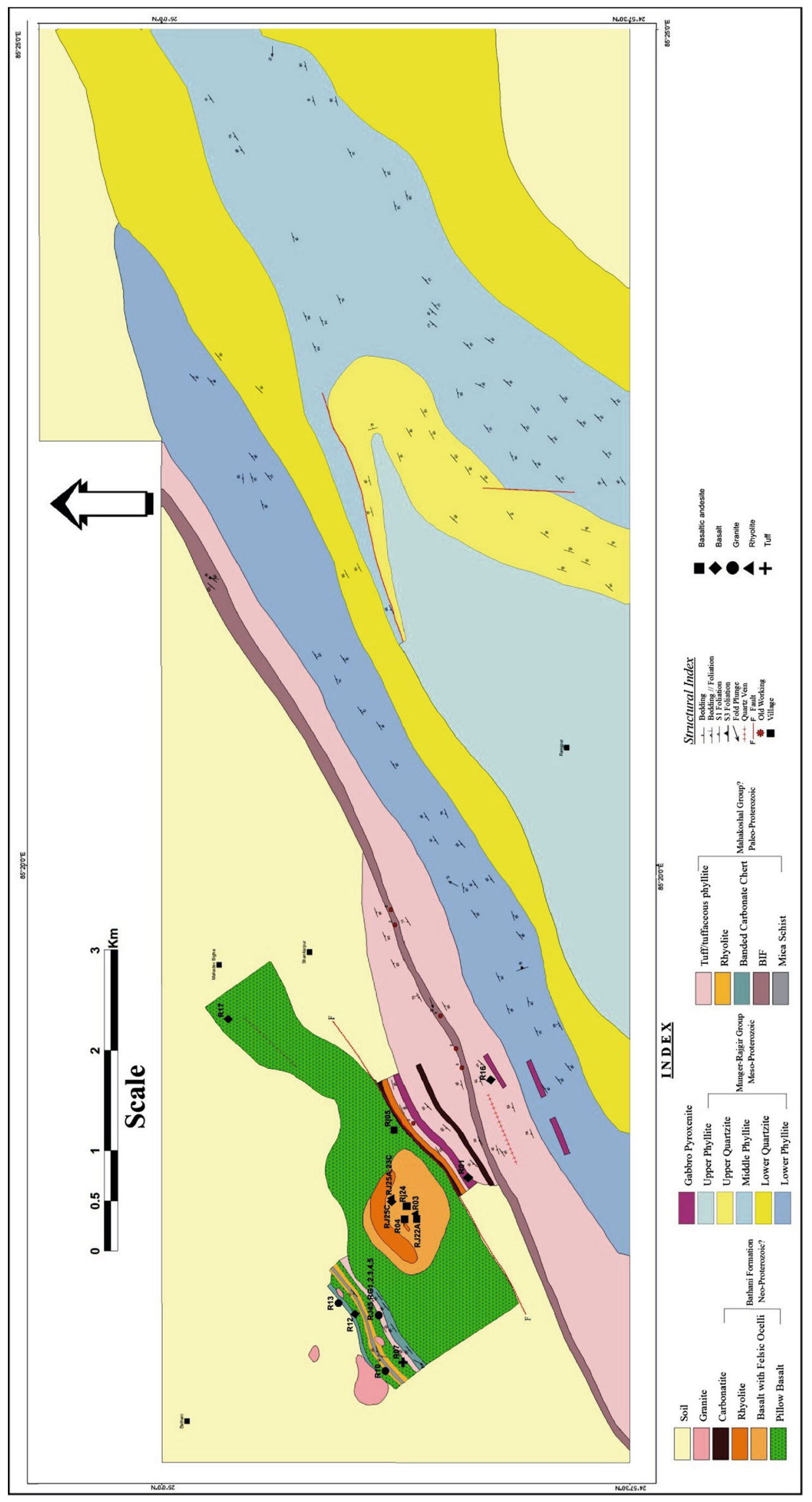

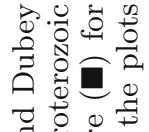

范苔券

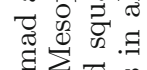

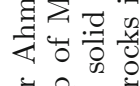

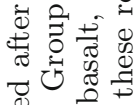

范落

远

类

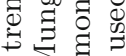

:

$\exists \Xi$

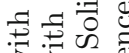

उह 3

要

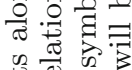

当者

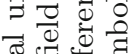

屴

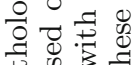

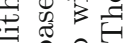

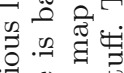

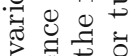

60

被政王

的

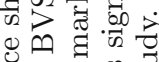

월

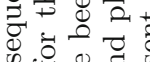

काष

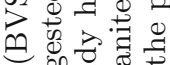

잉

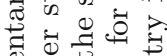

矛

कृ

1.000 .00

过

$\rightarrow$ 대을

긍 00

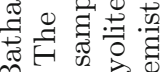

ص

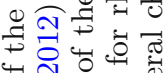

फृ

글 专 4.

寻

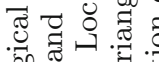

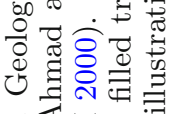

ง

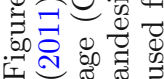



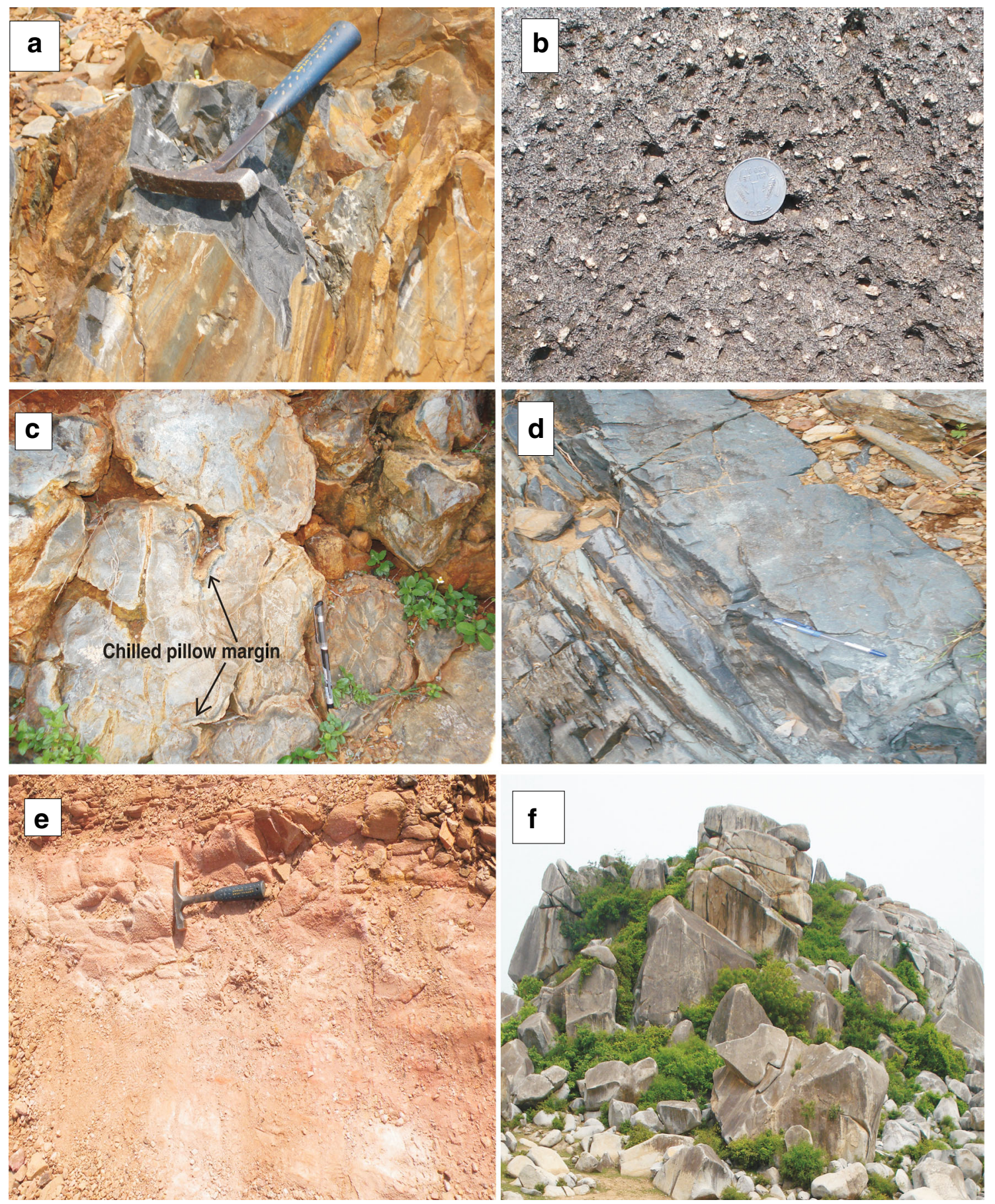

Figure 3. Field photographs of various rock types reported from the Bathani volcano-sedimentary (BVS) sequence. (a) An outcrop of rhyolite showing its banded nature $\left(24^{\circ} 58^{\prime} 39^{\prime \prime} \mathrm{N}, 85^{\circ} 17^{\prime} 55.1^{\prime \prime} \mathrm{E}\right)$. (b) An outcrop of andesite with prominent felsic ocelli $\left(24^{\circ} 58^{\prime} 40.6^{\prime \prime} \mathrm{N}, 85^{\circ} 17^{\prime} 57.5^{\prime \prime} \mathrm{E}\right)$. (c) A pillow basalt outcrop from Churi village of Gaya district with prominent radial cracks and chilled margin $\left(24^{\circ} 47^{\prime} 6.6^{\prime \prime} \mathrm{N}, 84^{\circ} 59^{\prime} 24.8^{\prime \prime} \mathrm{E}\right)$. (d) A basaltic flow outcrop from Ghansura area $\left(24^{\circ} 58.753^{\prime} 0^{\prime \prime} \mathrm{N}\right.$, $\left.85^{\circ} 18.432^{\prime} 0^{\prime \prime} \mathrm{E}\right)$. (e) A tuff layer in midst of a weathered terrain $\left(24^{\circ} 58^{\prime} 42.3^{\prime \prime} \mathrm{N}, 85^{\circ} 17^{\prime} 3.4^{\prime \prime} \mathrm{E}\right)$. (f) Granitic rock outcrop $\left(24^{\circ} 58^{\prime} 50^{\prime \prime} \mathrm{N}, 85^{\circ} 17^{\prime} 20^{\prime \prime} \mathrm{E}\right)$.

rhyolite flow bands occurring in association with the basaltic flows (figure 4e) and mafic clots within andesitic rocks (figure 4f). In the BVS sequence, rhyolite and basalt are observed as alternate flows in contact with each other. Andesites are mostly concentrated in the hybrid contact zones between the two. This indicates that the basaltic and the rhyolitic eruptions occurred concomitantly over a period of time. The formation of the andesite in the contact zone would at least require the two 

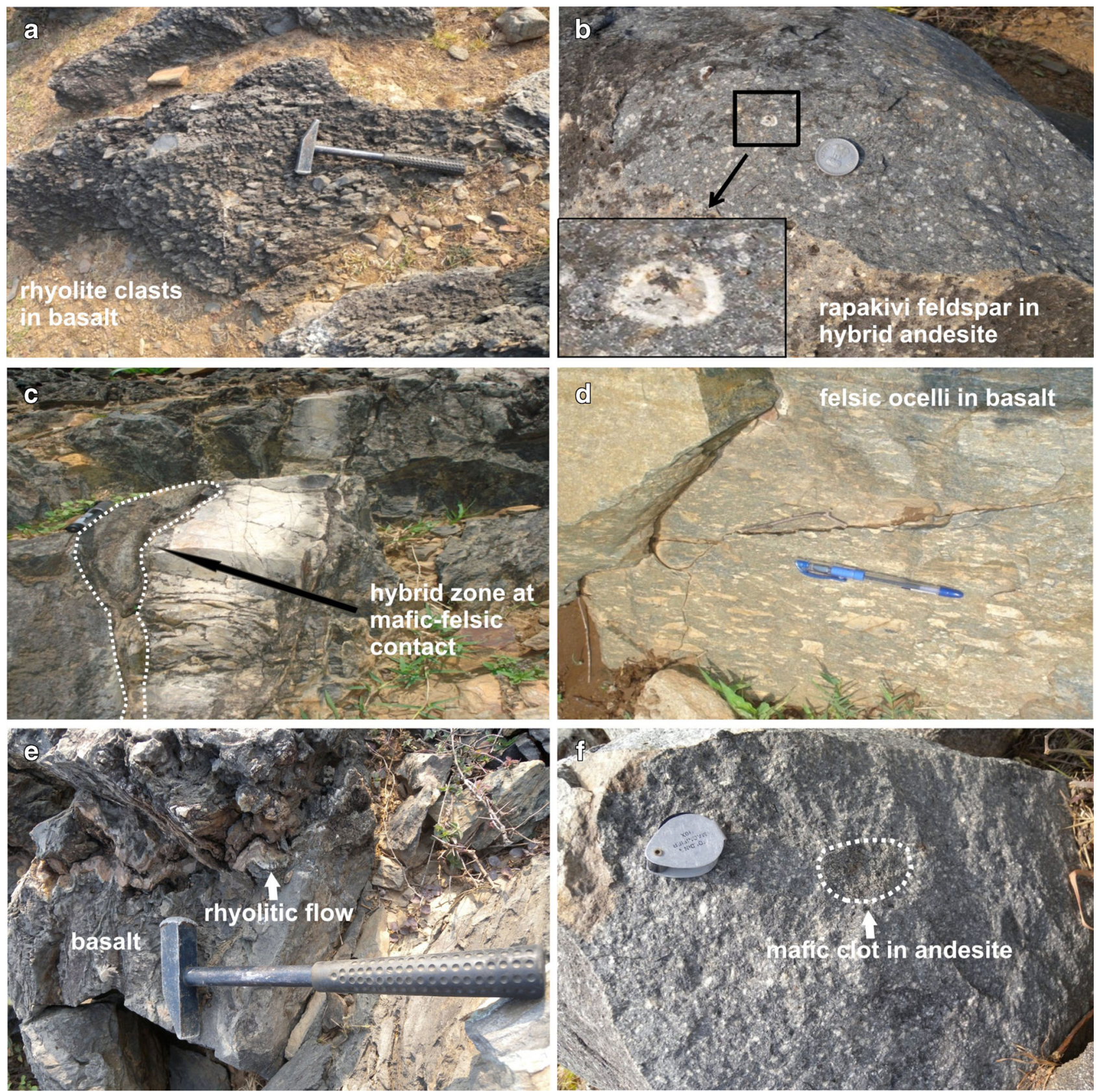

Figure 4. Field photographs showing various mixing and mingling structures and textures in rocks of BVS sequence. (a) Rhyolitic clasts in basalts $\left(24^{\circ} 58^{\prime} 39^{\prime \prime} \mathrm{N}, 85^{\circ} 17^{\prime} 55.1^{\prime \prime E}\right)$. (b) Growth of rapakivi feldspar in andesite suggestive of the changing melt composition $\left(24^{\circ} 58^{\prime} 40.6^{\prime \prime} \mathrm{N}, 85^{\circ} 17^{\prime} 57.5^{\prime \prime} \mathrm{E}\right)$. (c) Hybrid andesitic zone at mafic flow and felsic flow contact $\left(24^{\circ} 58^{\prime} 39.5^{\prime \prime} \mathrm{N}, 85^{\circ} 17^{\prime} 56^{\prime \prime} \mathrm{E}\right)$. (d) Occurrence of felsic ocelli in basalt $\left(24^{\circ} 58.753^{\prime} \mathrm{N}, 85^{\circ} 18.432^{\prime} \mathrm{E}\right)$. (e) Rhyolite flow occurring with basaltic flows $\left(24^{\circ} 58^{\prime} 40.6^{\prime \prime} \mathrm{N}, 85^{\circ} 17^{\prime} 57.5^{\prime \prime} \mathrm{E}\right)$. (f) Mafic clots within hybrid andesite indicative of entrapment of mafic magma in felsic magma due to mingling $\left(24^{\circ} 59.323^{\prime} \mathrm{N}, 85^{\circ} 15.627^{\prime} \mathrm{E}\right)$.

magma types to be in contact in fluid state for a definite interval of time for chemical interactions to occur. Though rhyolitic magma can be generated by fractional crystallization of basaltic magma, in the given scenario the basaltic and the rhyolitic magmas do not seem to be genetically related.

Southwest of our study area, Wanjari et al. (2012) have reported pillow basalts around Churi,
Jagannathpur, and Gulni villages and rhyolite occurrences from the Gere and Mirzapur villages within the Gaya district of Bihar. The $\mathrm{Rb}-\mathrm{Sr}$ whole rock dating of the Mirzapur rhyolites show a crystallization age of $1044 \pm 35$ Ma with an initial ${ }^{87} \mathrm{Sr} /{ }^{86} \mathrm{Sr}$ ratio of $0.8734 \pm 0.0088$ (Wanjari et al. 2012). The researchers remarked that the crystallization age of Mirzapur rhyolites coincides with the global Grenvillian event (1000 Ma) which 
had a major bearing in the tectono-thermal evolution of Neoproterozoic rocks and emplacement of acid volcanic and peraluminous granite plutons (Wanjari et al. 2012). The age of these rhyolites is similar to the whole rock isochron age of $1020.5 \pm$ 45.5 Ma of Meromako granite pluton of the BMB and the tonalitic gneisses $(995.5 \pm 31.1 \mathrm{Ma})$ of Canary Hill of Hazaribagh town which is believed to retain record of the fourth tectono-thermal event in CGGC (Mallick 1993).

This paper discusses the geochemical characteristics of these diverse volcanic rocks of BVS sequence along with the granite exposed in and around the Bathani village and proposes a model for their evolution. These are the first preMesoproterozoic magmatic rocks reported from the CGGC terrain. Geochemical characterization of the magmatic rocks of the BVS sequence will indeed augment our understanding of the tectonomagmatic events accountable for the evolution of CGGC.

\section{Petrography}

Petrographic study has been carried out on representative samples of basalt, andesite, rhyolite, tuff, and granite from the study area.

\subsection{Basalt}

The major mineral constituents of the basalt are augite and plagioclase feldspar while accessory phases include titanite, chlorite, iron oxides and alkali feldspar. Texturally, the basalts are holocrystalline and porphyritic in nature with phenocrysts of augite and plagioclase. Ophitic to subophitic texture (figure 5a) has been observed where plagioclase laths are partially or wholly engulfed within augite grains. Alteration of pyroxene to amphibole (figure 5b) is observed in basalts. In few samples pyroxenes have been totally replaced by amphiboles. Biotite at places is also altered to chlorite. Presence of secondary amphibole and chlorite may be attributed to low grade metamorphism setting in.

\subsection{Andesite}

Andesites appear holocrystalline, hypidiomorphic, and porphyritic with phenocrysts of quartz, plagioclase, and biotite in a fine-to-medium grained groundmass of quartz, feldspar, biotite, calcite, and iron oxide. Oscillatory zoning in plagioclase feldspar (figure 5c), quartz ocelli, presence of resorbed plagioclase grains (figure $5 \mathrm{~d}$ ) and acicular apatite (figure 5e) have been observed which are indicative of hybrid nature of the andesites. In some andesites, mafic clots (figure 5f) are also found preserved.

\subsection{Tuff}

The tuffs are fine grained with abundant broken fragments of euhedral to anhedral muscovite (figure $5 \mathrm{~g}$ ) set in a matrix of subrounded quartz and fine grained alkali feldspar embedded in a devitrified glass (figure $5 \mathrm{~h}$ ). Tourmaline is also observed in some tuffs. Uneven distribution of broken crystals is characteristic of rocks derived from explosive environments. The glassy component occurs concentrated along irregular bands.

\subsection{Rhyolite}

The major constituent phases of the rhyolites are alkali feldspar, quartz, muscovite, and iron oxides. They are fine grained and holocrystalline. The grain shapes vary from subhedral to anhedral. The rhyolites show quartz-rich and muscovite-rich layers, thus giving the rock a banded appearance (figure 5i). This bandings are probably because of deformation undergone by the rocks.

\subsection{Granite}

The major phases in granites are feldspar, biotite, and quartz. Chlorite, muscovite, sericite, epidote, titanite, and iron oxide occur as accessory phases (figure 5j). Texturally, these are coarse-to-medium grained, holocrystalline, and leucocratic rocks with grain shapes varying from subhedral to anhedral. The vermicular intergrowth of quartz and feldspar (figure 5k) in the granite provides textural evidence of late stage simultaneous growth of quartz and feldspar in an extremely differentiated magma source. Perthitic exsolution (figure 5l) is common in granites.

\section{Mineral chemistry}

Mineral chemical analyses of various minerals in the basalt, andesite, rhyolite, tuff, and granite were determined using a CAMECA SX 100 electron microprobe with acceleration voltage of $15 \mathrm{kV}$ and beam current of $10 \mathrm{nA}$ at the Electron Microprobe Analyzer Laboratory, Geological Survey of India, Faridabad. Analyses were carried out with a beam diameter on $1 \mu \mathrm{m}$. Standards used include Wollastonite for Si and $\mathrm{Ca}$, Periclase for $\mathrm{Mg}$, Rhodonite for Mn, Albite for Na, Corundum for Al, Hematite for Fe, Orthoclase for K, Apatite for P, Metallic Cr and $\mathrm{Ti}$ for $\mathrm{Cr}$ and $\mathrm{Ti}$, Halite for $\mathrm{Cl}$, Metallic $\mathrm{Zn}$ for Zn, Fluorite for F, and Barite for Ba. The correction applied to the data is that of PAP (Pouchou and Pichoir 1987). 


\subsection{Basalt}

In basalts, the feldspar is of plagioclase composition. The chemical composition of feldspar represents a solid solution between albite and anorthite. The $\mathrm{X}_{\mathrm{Na}}$ content varies from $0.45-0.64$ (figure $6 \mathrm{a}$ ) and $\mathrm{X}_{\mathrm{Ca}}$ varies from $0.34-0.54$ (table 1 ).
The pyroxene data shows a solid solution between enstatite, ferrosilite and wollastonite. The EPMA data of pyroxene from basalts have been documented in table 1 . The end member calculation of pyroxene has been done on the basis of six oxygen (Cawthorn and Collerson 1974) and ferrous and ferric Fe content has been calculated
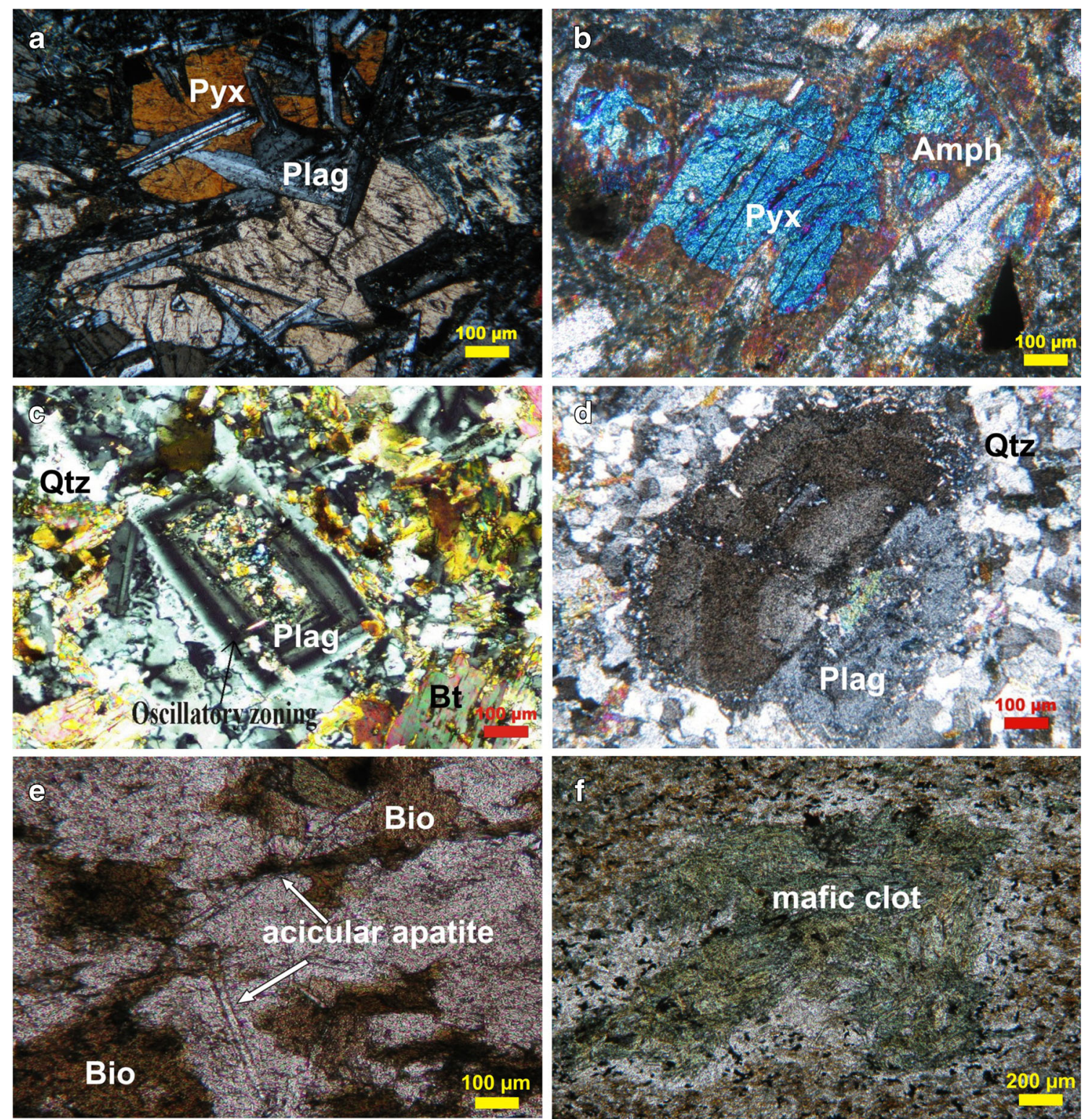

Figure 5. Photomicrographs of various rock types illustrating textural features of different rocks from BVS sequence. (a) Basalt showing ophitic texture with plagioclase laths enclosed in augite (sample no. R01). (b) A pyroxene grain in basalt with alteration rim of amphibole at its grain boundary (sample no. RD30). (c) Andesite with oscillatory zoned plagioclase indicating disequilibrium growth (sample no. R04). (d) Resorbed plagioclase grain in andesite formed due to disintegration of an earlier formed plagioclase grain getting re-equilibrated in the new hybrid melt (sample no. RJ24). (e) Growth of acicular apatite in andesite due to quenching of hot mafic magma by relatively colder felsic magma (sample no. R04). (f) Mafic mineral clot in hybrid rock (sample no. RJ22B). (g) A fine grained tuff showing broken fragments of muscovite in a devitrified glassy matrix suggests an explosive eruption (sample no. R07). (h) Tuff showing subrounded grains of K-feldspar and quartz and broken fragments of muscovite embedded in a devitrified glassy matrix (sample no. R07). (i) Rhyolite showing alternating bands of mica and quartz rich layers. Such bands may develop as a result of deformation (sample no. R04). (j) Granite showing euhedral biotite grains occurring with euhedral to subhedral plagioclase and quartz grains (sample no. RD29). (k) Myrmekite texture in granite (sample no. RD28). (1) Perthitic intergrowth in granite (sample no. RD34). 

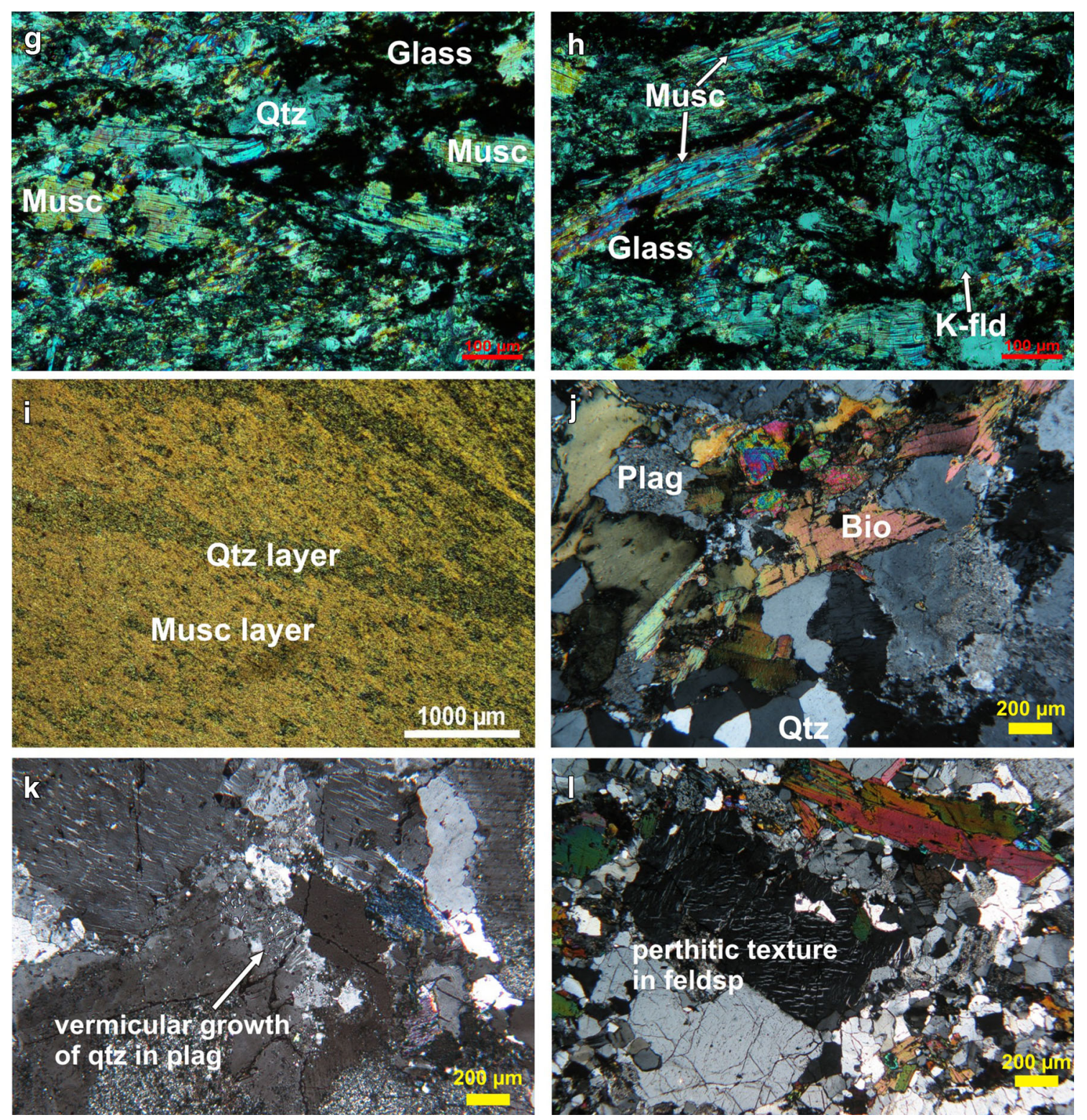

Figure 5. (Continued.)

according to Droop (1987). The chemical data of pyroxene of the basalts show a restricted end member composition $\left(\mathrm{Wo}_{40-43} \mathrm{En}_{36-38} \mathrm{Fs}_{18-22}\right)$. Figure $6(\mathrm{~b})$ shows the composition of clinopyroxene grains of the basalts in terms of end member compositions. Almost all data plot within the augite field.

Micas of the present area have been classified based on classification given by Deer et al. (1992). Mica minerals have been further subdivided on the basis of $\mathrm{Si}, \mathrm{Al}$ and $(\mathrm{Mg}, \mathrm{Fe})$ value of atoms per formula unit. Basalts have biotite as the mica mineral showing a solid solution between annite and siderophyllite end members (Speer 1984). The Si content of biotite grains vary from 5.43-6.10 and total $\mathrm{Al}$ varies from
2.29-3.47 (figure 6d). The $\mathrm{Fe}+\mathrm{Mg}$ value ranges from 3.91-5.45 mol fractions (22O) and Ti content varies from $0.04-0.28$. Low total observed for the biotite is because of the alteration of the biotite to chlorite.

Chlorite is mostly occurring as secondary phase. The Si content for chlorite varies from $6.59-5.30$ with $\mathrm{Al}$ content of $5.69-3.88$.

Amphibole is reported only from the basalts of the study area. Mineral formula calculation for the amphibole has been carried out following Leake et al. (1997). Amphibole is commonly actinolite and magnesium hornblende with $\mathrm{Mg}$ percentage varying from 12-14 wt\% and with low $\mathrm{Ti}$ content of $<1 \mathrm{wt} \%$ (figure $6 \mathrm{f}$ ). Amphibole chemistry could not be used for the purpose of estimating the 
pressure-temperature conditions of the magma chamber as the amphibole compositions plot within the metamorphic field of the calcic amphibole discrimination diagram of Fleet and Barnett (1978). They are probably crystallized due to metamorphic equilibration.

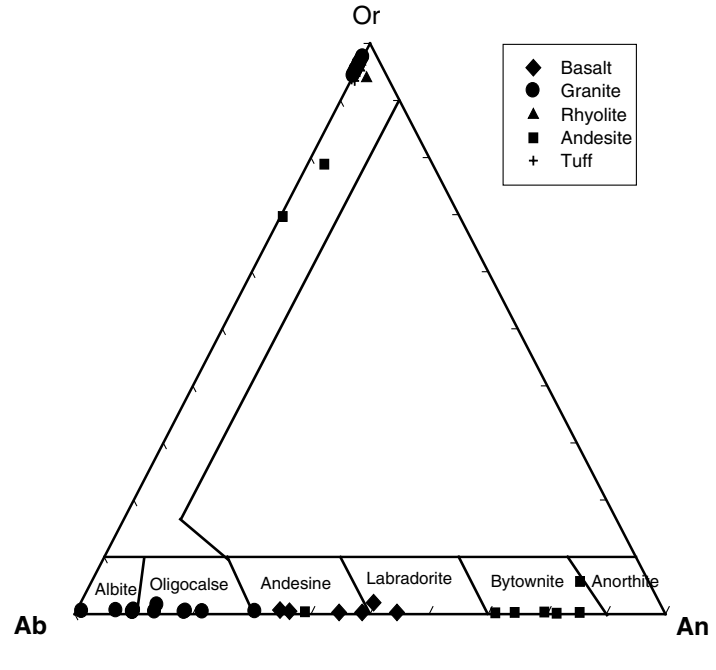

a

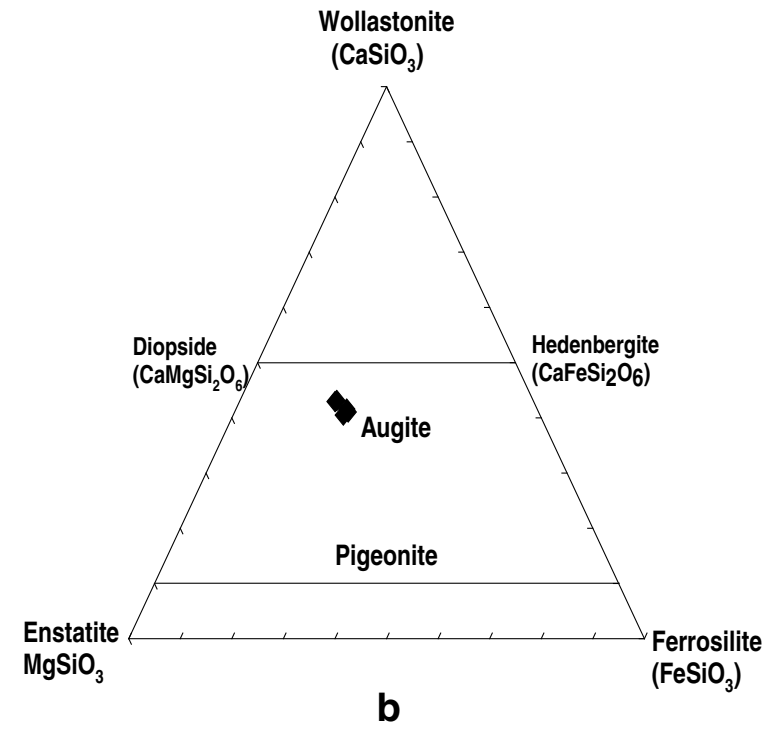

b

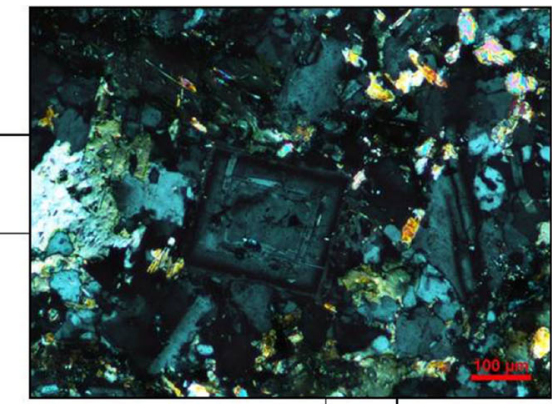

1.00
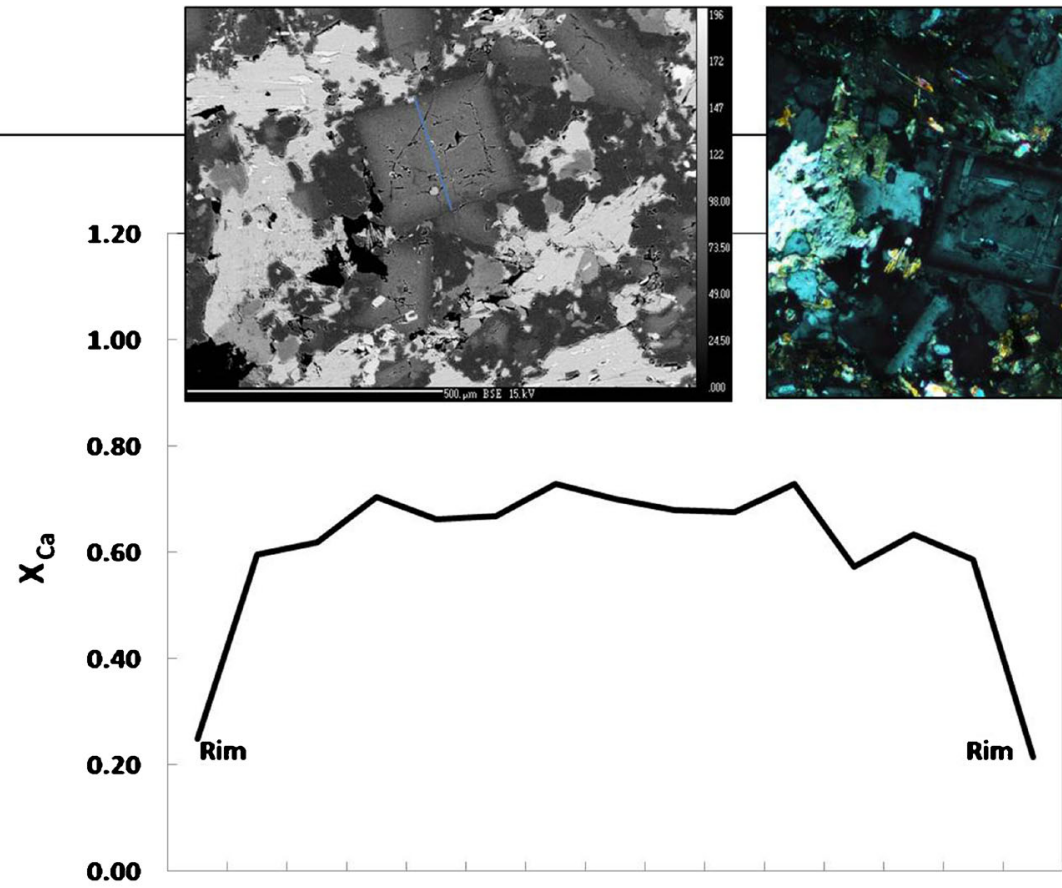

1

\section{No of analysis}

c

Figure 6. (a) A triangular plot showing the composition of the feldspars of the various rock types of BVS sequence Deer et al. (1992). (b) Composition of pyroxene grains of the basalt samples of the BVS sequence. The end member calculations of the pyroxene have been done on the basis of 6 oxygen (Cawthorn and Collerson 1974). (c) Compositional profile of an oscillatory zoned plagioclase grain of andesite (sample no. R04). The compositional variability shown as a function of $\mathrm{X}_{\mathrm{Ca}}$ content marks the disequilibrium growth of the mineral (see table 2). (d) (i) Classification of biotite from basalt, andesite and granite of BVS sequence based on the nomenclature of Speer (1984). (ii) A plot showing the $\mathrm{Mg}-\mathrm{Fe}$ compositional variation of biotite in mafic, felsic and intermediate rocks of the BVS sequence. (e) Plot showing the total range of Phengitic substitution in the muscovite grains of tuff, rhyolites and granites of the BVS sequence Deer et al. (1992). (f) Classification plot of amphibole from basalt of the BVS sequence after Leake et al. (1997). 
(i)
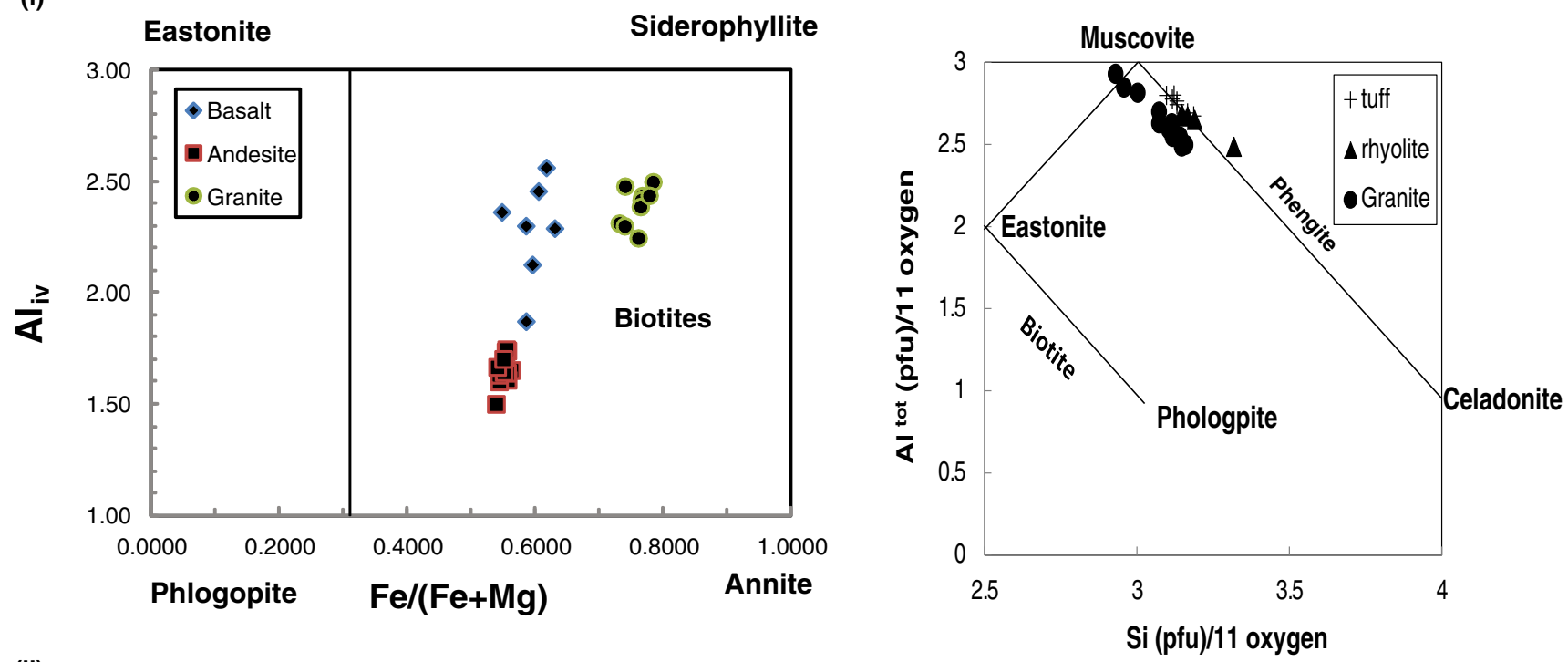

(ii)
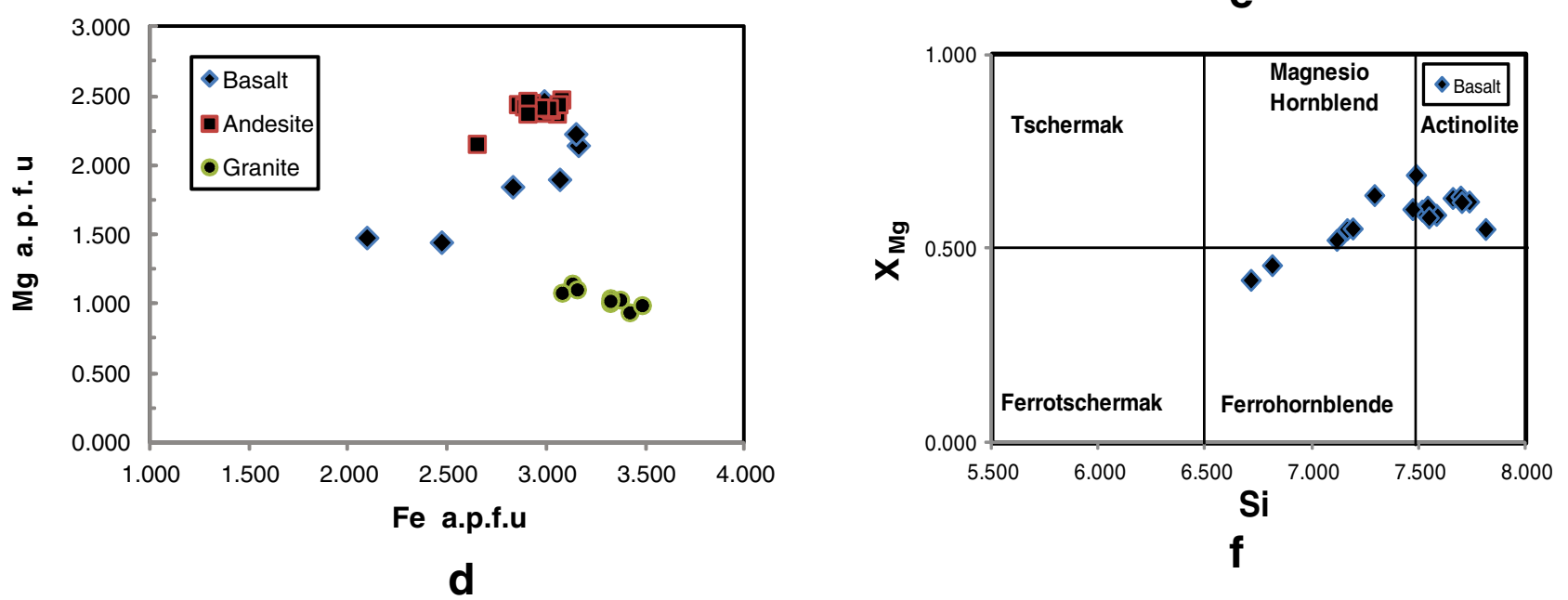

Figure 6. (Continued.)

\subsection{Andesite}

Andesites have feldspars of both plagioclase and alkali feldspar compositions. The andesite plagioclase composition is rich in $\mathrm{Ca}$ content with $\mathrm{X}_{\mathrm{Ca}}$ value varying from $0.71-0.85$ with a corresponding $\mathrm{X}_{\mathrm{Na}}$ value of $0.14-0.28$. However, in the plagioclase grains with oscillatory zones, composition ranges from albite-rich rims to anorthite-rich cores. A zoning profile of $\mathrm{X}_{\mathrm{Ca}}$ content for a plagioclase grain illustrating disequilibrium growth is shown in figure 6(c) (see table 2). For the alkali feldspar of andesite, the $\mathrm{X}_{\mathrm{K}}$ content ranges from 0.69-0.95. Andesites have biotite as the mica mineral. According to the nomenclature of biotite based on Speer (1984), biotite of the andesites is solid solution of annite and siderophylite end members with a $\mathrm{Si}$ value varying from 6.23-6.49 and total $\mathrm{Al}=1.65-1.96$ (figure $6 \mathrm{~d}$ ).

\subsection{Tuff}

Alkali feldspar compositions are observed for tuff with $\mathrm{X}_{\mathrm{K}}$ content of 0.93-0.94. Mica in the tuff is muscovite with $\mathrm{Si}$ content of 6.29-6.63 p.f.u, $\mathrm{Mg}+\mathrm{Fe}$ content of $0.29-0.38$ p.f.u and $\mathrm{Al}$ content of $4.96-5.36$ p.f.u and $\mathrm{X}_{\mathrm{K}}$ varies from $0.95-0.97$ (figure 6e).

\subsection{Rhyolite}

The alkali feldspar of rhyolite shows $\mathrm{X}_{\mathrm{K}}$ content of $93-95 \mathrm{~mol} \%$. Muscovite grains are observed in rhyolites with $\mathrm{X}_{\mathrm{K}}$ varying from $0.93-0.98$. Si vs. total $\mathrm{Al}$ plot clearly shows that they are ideal muscovite with a limited phengitic substitution (figure 6e). Ilmenite grains are also observed in the rhyolite. Cation calculation for the ilmenite has been done on the basis of $3 \mathrm{O}$ as given in table 1 . 


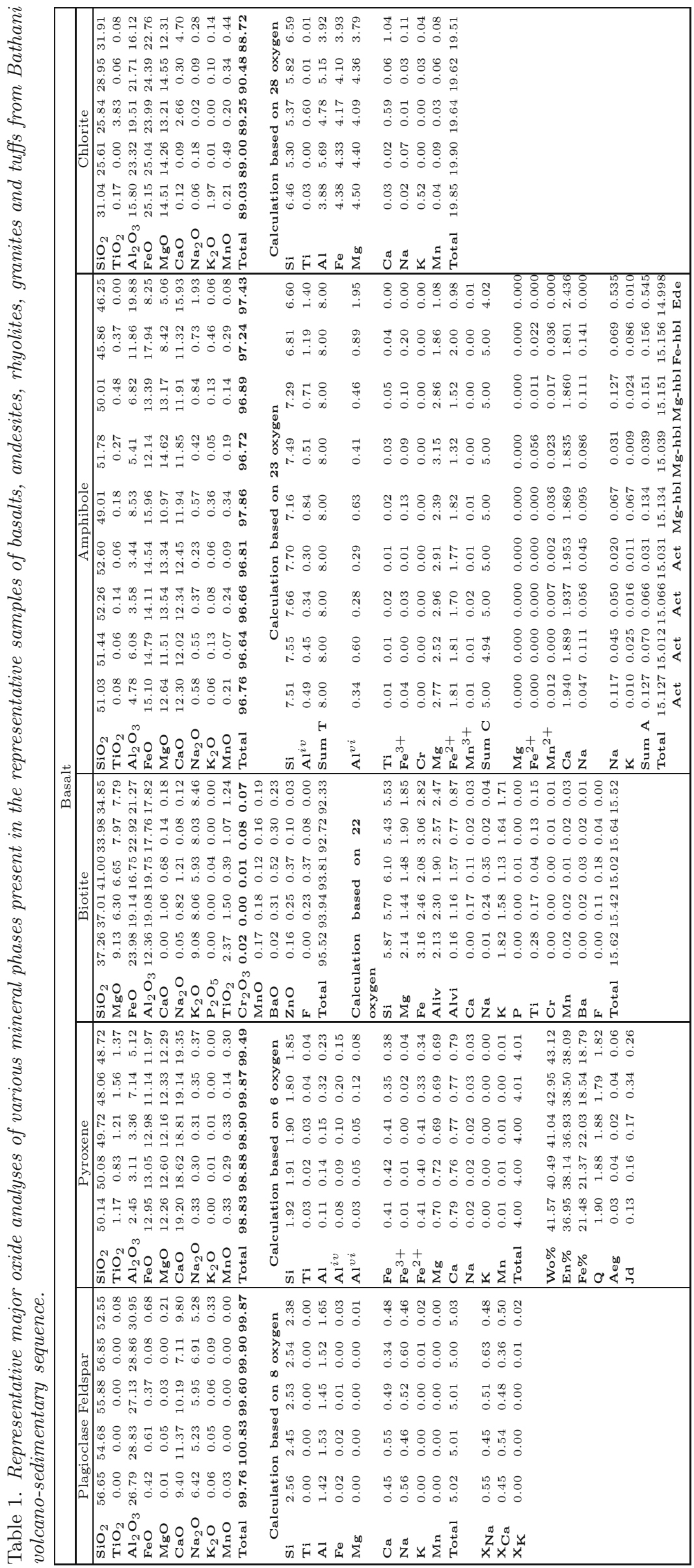


药

ำ ㄱำ

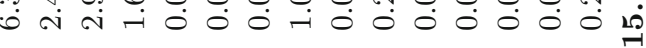

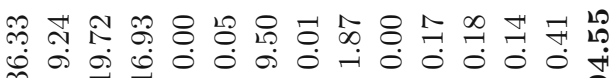

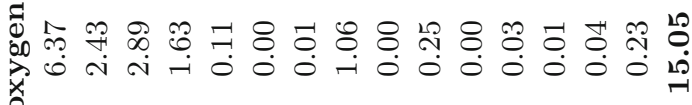

ง

ฟ 2 \&

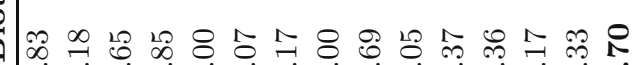

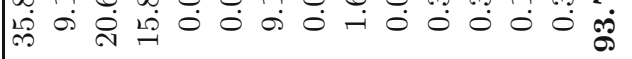

잉 $\infty$ ஜ

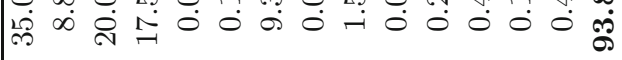

五

敢

ฮิ

而定

茪

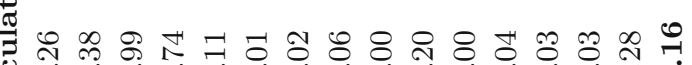
U

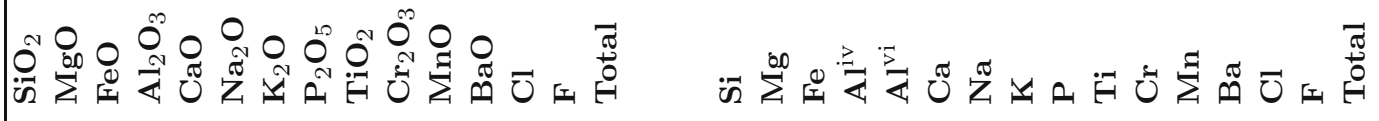

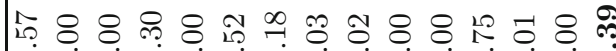

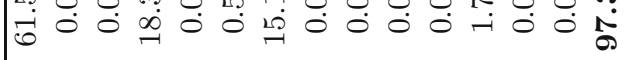

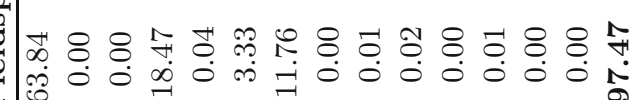

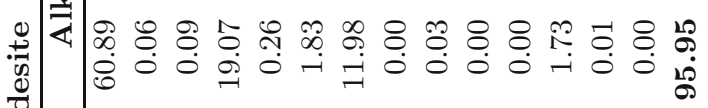

赵

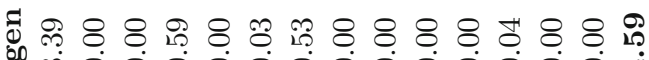

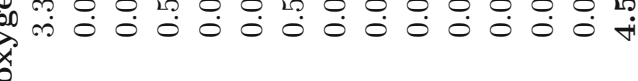

$\begin{array}{lll}12 & 12 & 0 \\ 9 & 0 & 0 \\ 0 & 0 & 0 \\ 0 & 0 & 0\end{array}$

ธี

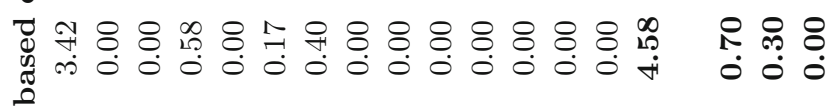

章泀

ขึ

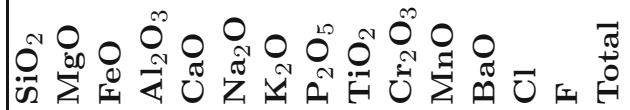

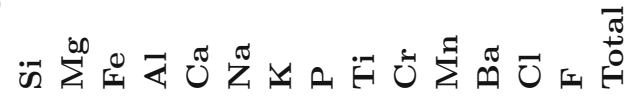

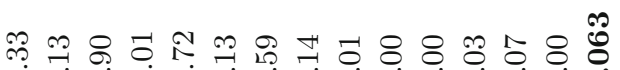

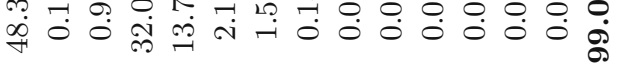

ํ. 후

$\begin{array}{lll}\text { N1 } & \infty & 0 \\ & \infty & 0 \\ 0 & 0 & 0\end{array}$

ஜ

ن.

สี

约 \&

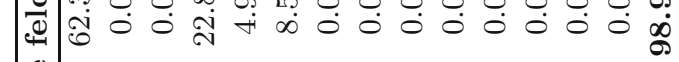

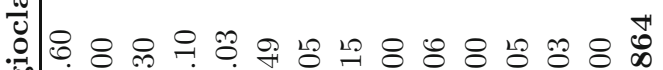
药

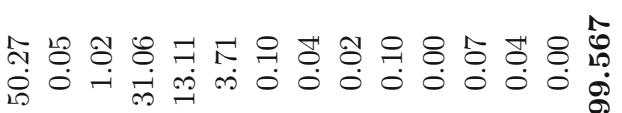

ஜ \& \&

ำ 동 络

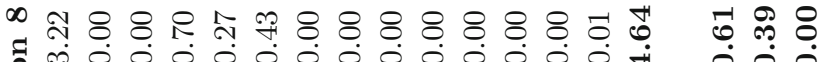
हैं

ก : $\frac{\sqrt[\pi]{3}}{3}$

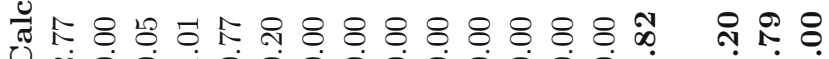

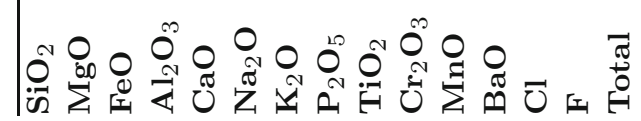

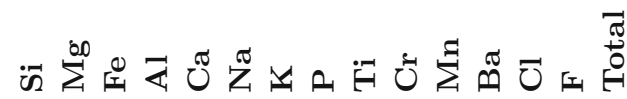




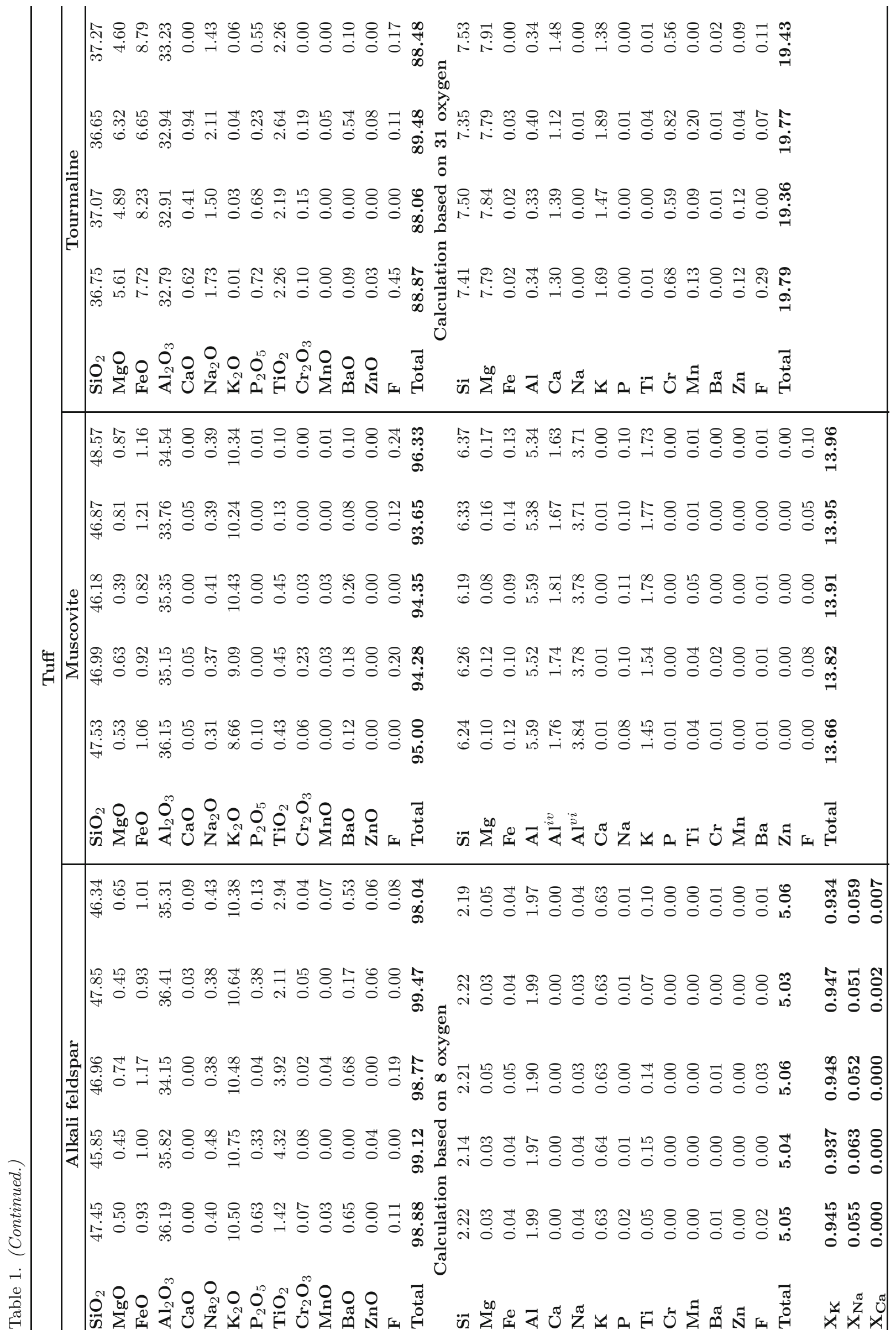




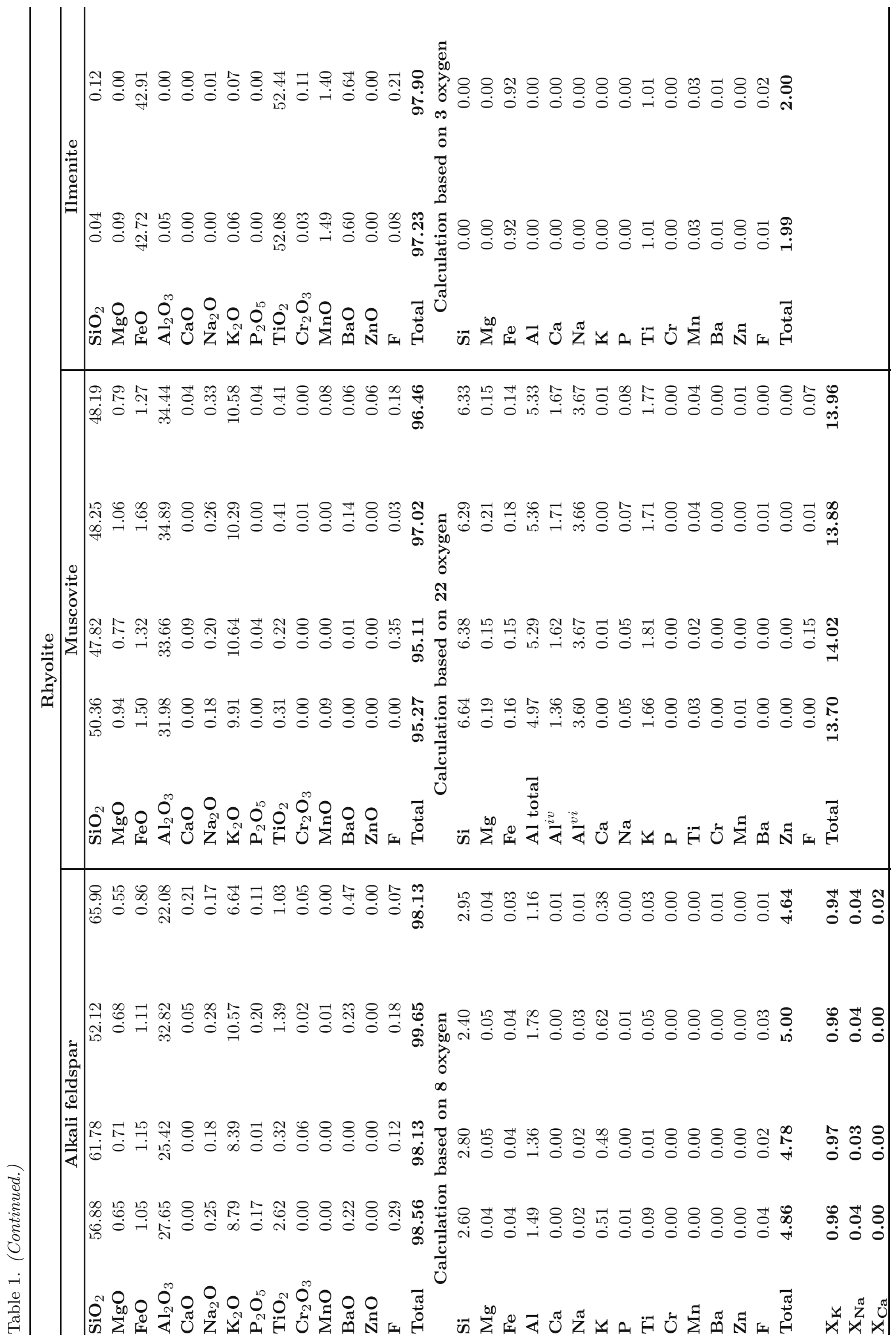




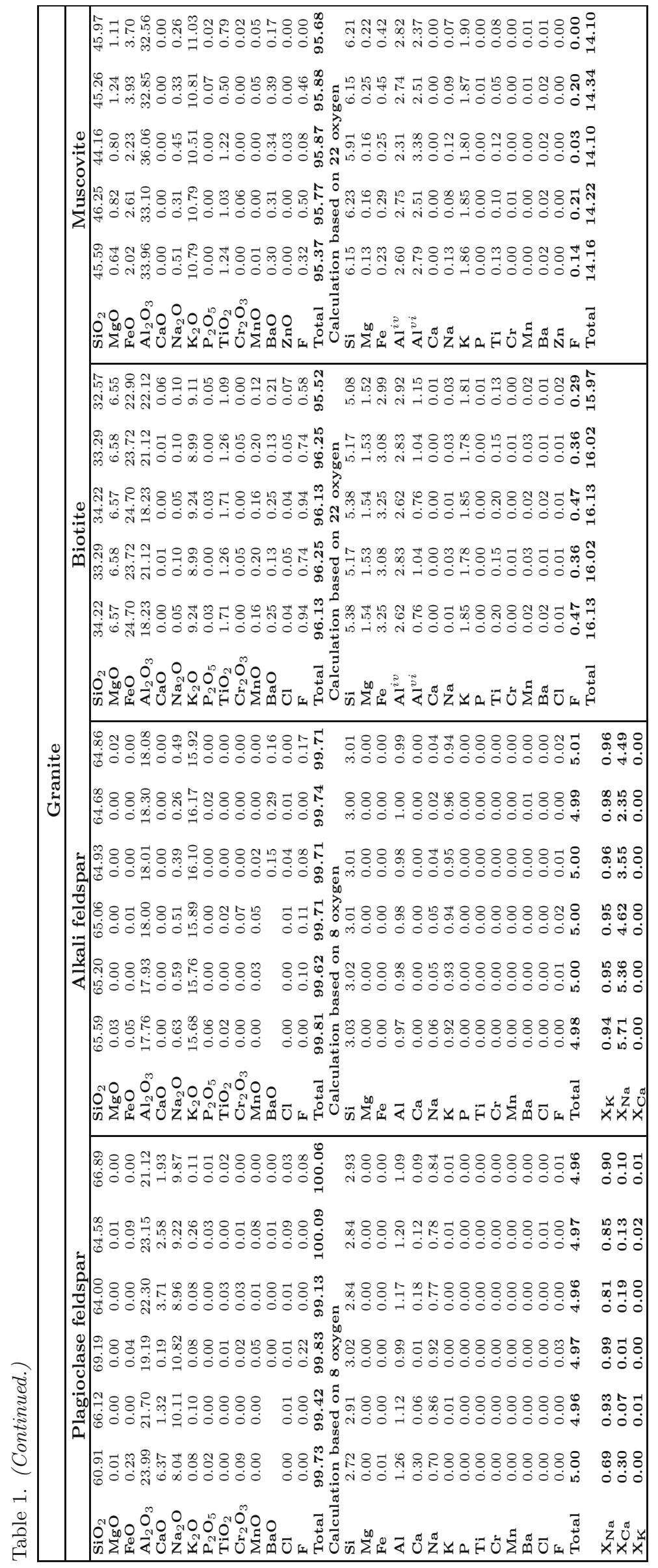




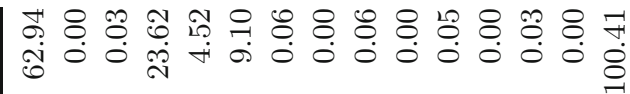

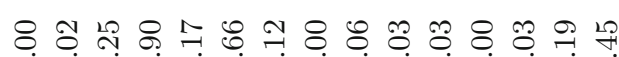

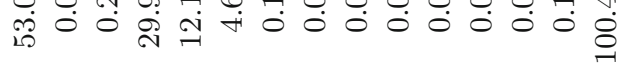

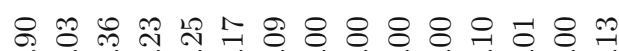

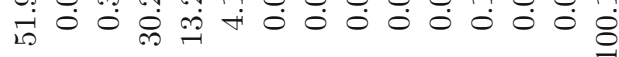

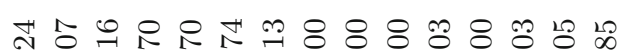

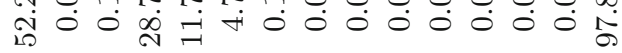

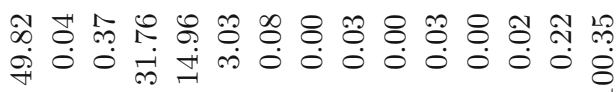

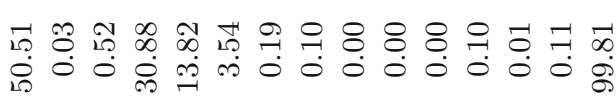

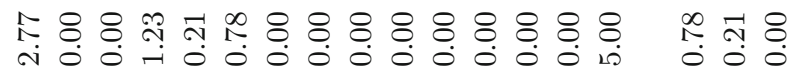

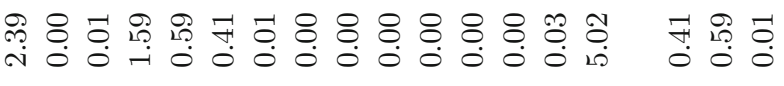

กิ \&

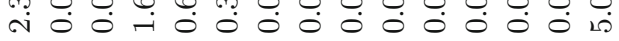

ஜ

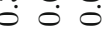

강

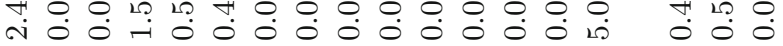

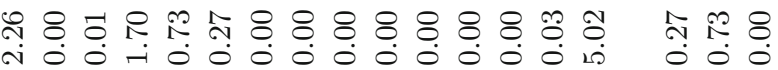

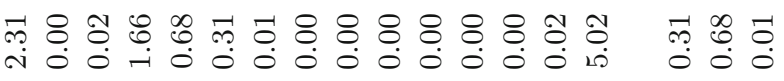

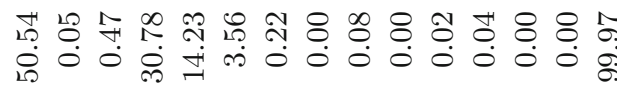

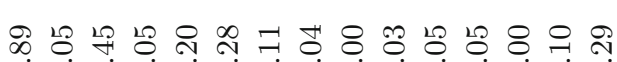

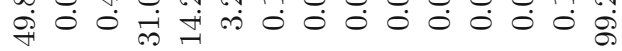

จ \& จ

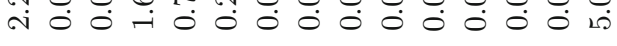

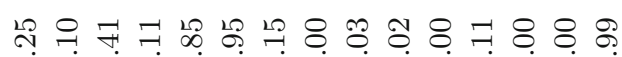

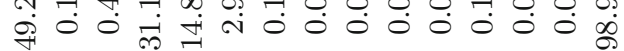

光

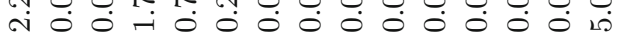

붕

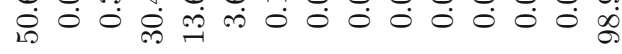

낙 둥

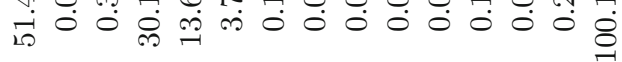

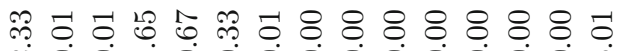

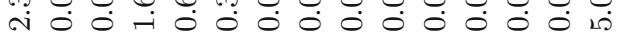

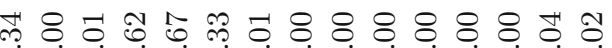

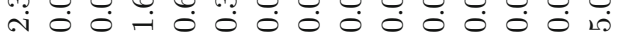

œ

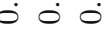

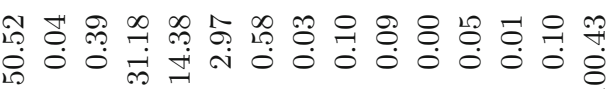

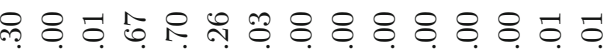

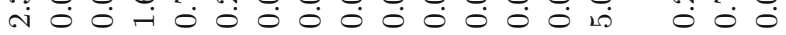

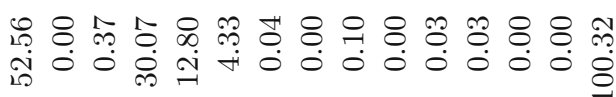

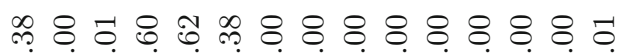

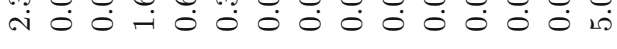

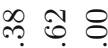
$\circ 0$

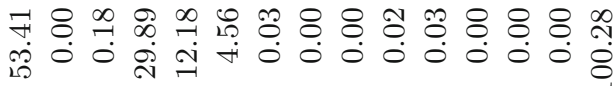

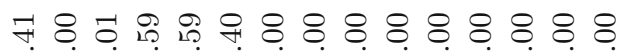

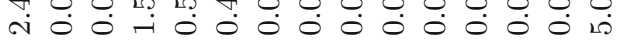
유요요

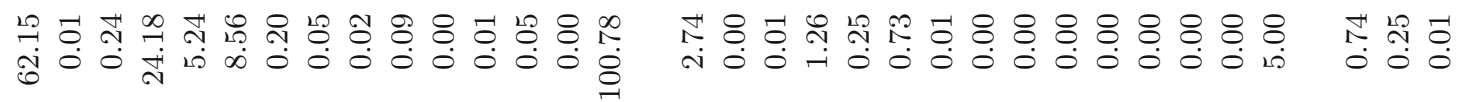


Ilmenite shows $\mathrm{Ti}=1.01$ and $\mathrm{Fe}^{2+}=0.92 \mathrm{~mol}$ fraction per formula unit.

\subsection{Granite}

The granite has feldspars of both plagioclase and alkali feldspar composition (figure 6a). The plagioclase feldspars are enriched in albite component with $\mathrm{X}_{\mathrm{Na}}$ varying from $0.69-0.98$. The granite has an alkali feldspar composition with $\mathrm{X}_{\mathrm{K}}$ ranging from 0.94-0.97. Biotite and muscovite are present in the granite. Biotite is a solid solution of annite and siderophyllite having a $\mathrm{Si}$ value varying from 5.52-5.69 and total $\mathrm{Al}$ varying from 3.13-3.55 (figure 6d). The $\mathrm{Fe}+\mathrm{Mg}$ values range from 4.16-4.47. The muscovite show limited phengitic substitution.

The general trend of decreasing $\mathrm{X}_{\mathrm{Ca}}$ content of plagioclase feldspar composition from the basalt to the granite indicates fractional crystallization of basaltic magma to produce granitic magma. Biotite composition from the basalt to the granite shows a decrease in $\mathrm{Mg}$ content with a corresponding increase in $\mathrm{Fe} / \mathrm{Fe}+\mathrm{Mg}$ content, pointing towards fractionation of granites from the basalts. However, the biotite from the andesite plots as a distinct composition group from the granite and basalt. It can be inferred that this might be due to mixing of felsic and mafic melts.

\section{Geochemistry}

\subsection{Geochemical analytical methods adopted}

A total of 18 bulk rock samples (5 basalts, 4 andesites, 3 rhyolites, 1 tuff, and 5 granites) were analysed for major oxides, trace elements and rare earth elements (tables 3 and 4). Major oxides and trace elements were analysed using XRF (Bruker S8 Tiger Sequential X-ray Spectrometer with Rh excitation source) following the procedure of Saini et al. $(1998,2000)$ and rare earth elements (REEs) were analysed using ICP-MS (PerkinElmer made SCIEX quadrapole type ICP-MS, ELAN DRC-e), at the Wadia Institute of Himalayan Geology, Dehradun (India).

Operating conditions for the major oxides were: no filter, vacuum path, $20 / 40 \mathrm{kV}$; for trace elements: no filter, vacuum path, $55 / 60 \mathrm{kV}$. The overall accuracy in relative standard deviation percentage is $<5 \%$ for major and minor oxides and $<12 \%$ for the trace elements. The average precision is better than 2.0\% (Purohit et al. 2006; Saini et al. 2007).

Sample solutions were introduced for rare earth element analysis into the argon plasma using a peristaltic pump and a cross flow nebulizer.

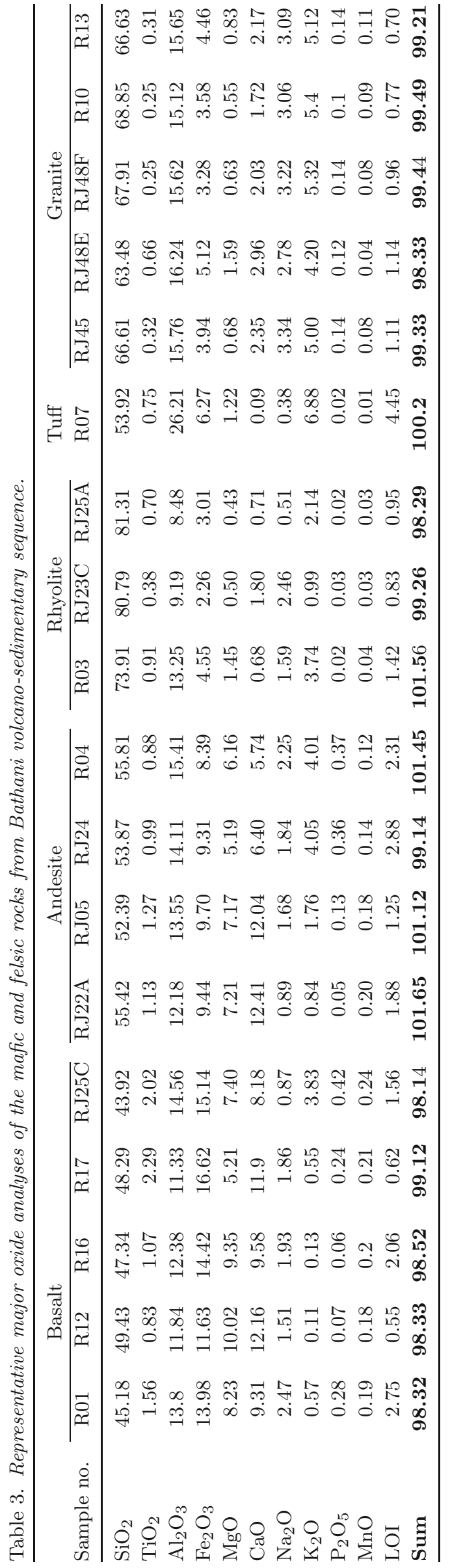




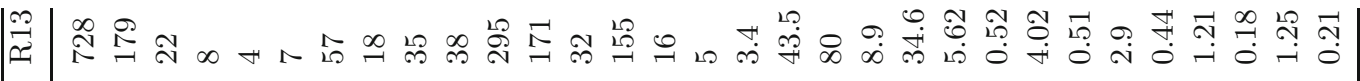

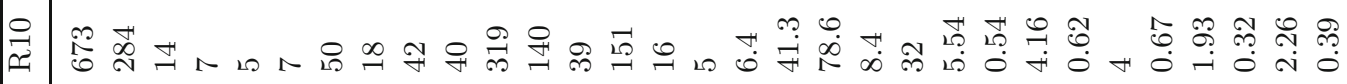

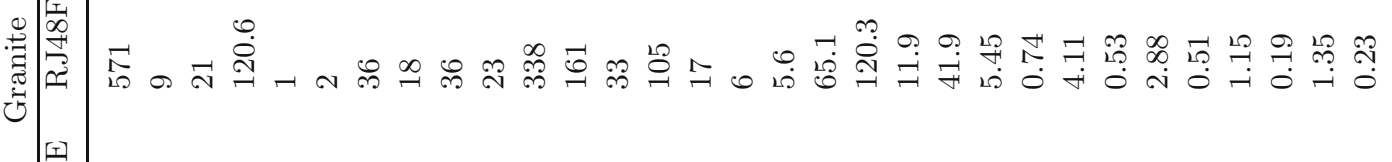

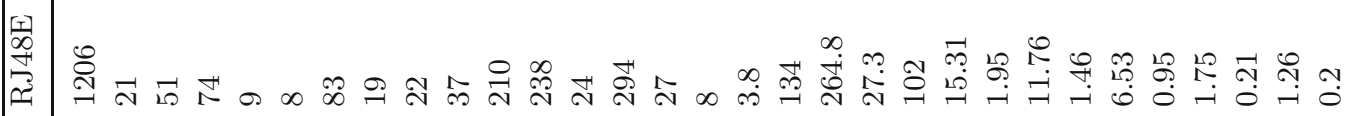

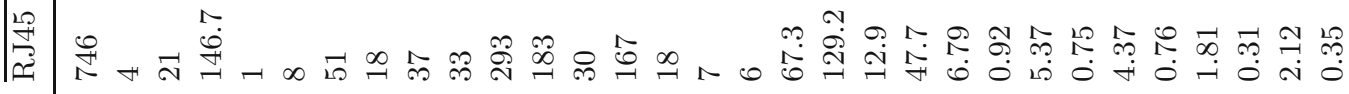

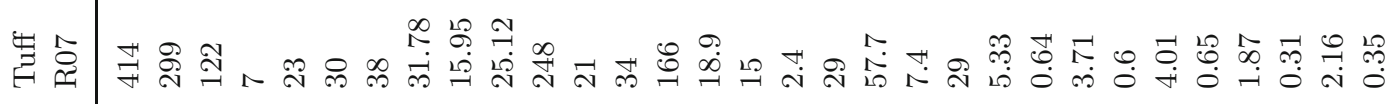
|艹 象

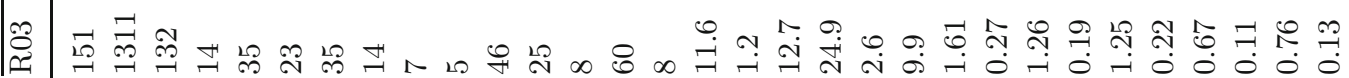

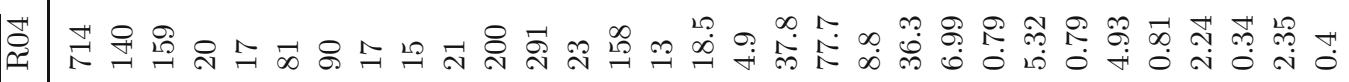

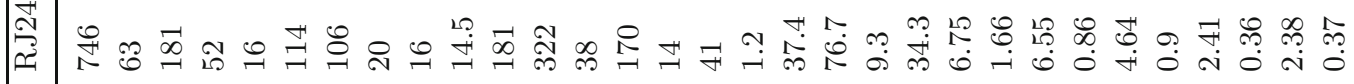

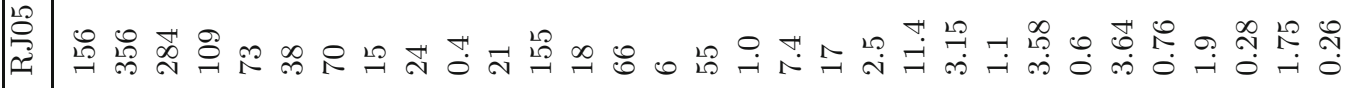
芠

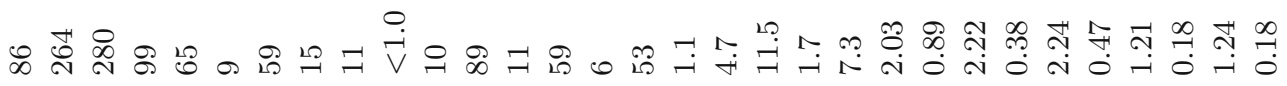

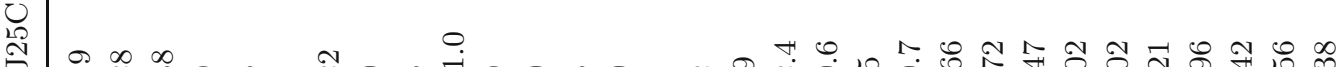

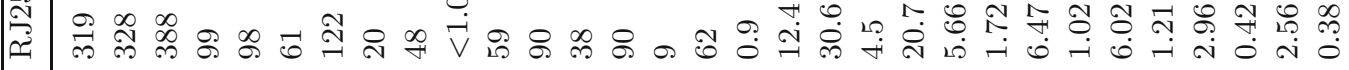

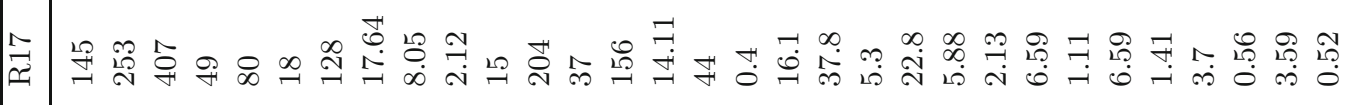

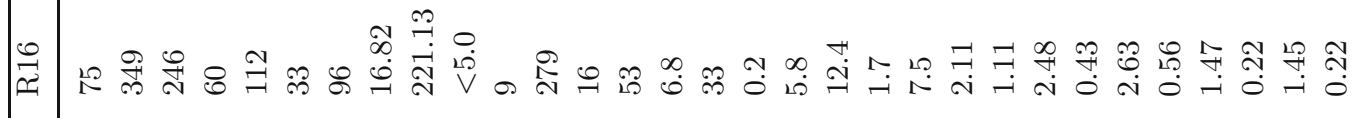

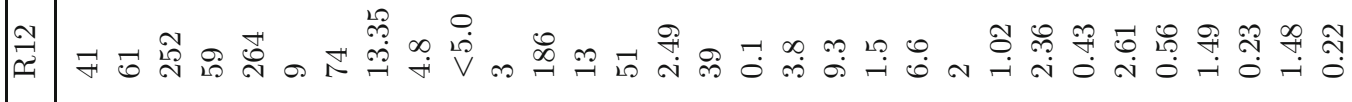
在 : 路> 
The procedures adopted for sample digestion and preparation of solutions were that of Balaram et al. (1990). USGS (BHVO-1, AGV-1) and JGS (JG-2, RGM-1) samples were used as rock standards to minimize matrix effect. RSD for most of the samples is better than $10 \%$.

\subsection{Geochemical results and interpretations}

\subsubsection{Major oxides}

Major oxide data for the studied samples of the different rock types are presented in table 3 . The $\mathrm{SiO}_{2}$ content for basalt ranges from $43.92-49.43 \mathrm{wt} \%$, for granite $63.48-68.85 \mathrm{wt} \%$, for andesite from 52.39 $55.81 \mathrm{wt} \%$, and for rhyolite 73.91-81.31 wt\%. Basalts contain 1.62-4.7 wt\% $\mathrm{K}_{2} \mathrm{O}+\mathrm{Na}_{2} \mathrm{O}, 11.63-$ 16.62 wt\% $\quad \mathrm{Fe}_{2} \mathrm{O}_{3}, 5.21-10.02 \quad \mathrm{wt} \% \mathrm{MgO}, 0.83-$ $2.29 \mathrm{wt} \% \mathrm{TiO}_{2}$, and 0.06-0.42 wt\% $\mathrm{P}_{2} \mathrm{O}_{5}$. Basaltic andesites have $\mathrm{K}_{2} \mathrm{O}+\mathrm{Na}_{2} \mathrm{O}$ content of $1.73-$ 6.26 wt\%, total $\mathrm{Fe}_{2} \mathrm{O}_{3}$ of $8.39-9.44$ wt\%, and $\mathrm{MgO}$ content of 5.19-7.21 wt\%. For the rhyolite, $\mathrm{K}_{2} \mathrm{O}+\mathrm{Na}_{2} \mathrm{O}$ content varies from $2.65-5.33 \mathrm{wt} \%$, $\mathrm{Fe}_{2} \mathrm{O}_{3}$ content varies from 2.26-4.55 wt\%, and the $\mathrm{MgO}$ content varies from $0.43-1.45 \mathrm{wt} \%$. The granites are characterized by $6.98-8.54 \mathrm{wt} \% \mathrm{~K}_{2} \mathrm{O}+$ $\mathrm{Na}_{2} \mathrm{O}, 3.28-5.12$ wt\% $\mathrm{Fe}_{2} \mathrm{O}_{3}, 0.25-0.66$ wt\% $\mathrm{TiO}_{2}$, $0.55-1.59$ wt\% $\mathrm{MgO}$, and $0.10-0.14 \mathrm{wt} \% \mathrm{P}_{2} \mathrm{O}_{5}$.

Secondary minerals like chlorite, epidote and amphibole have been observed optically in rock thin sections. Their formation from pre-existing minerals by alteration may be attributed to low grade metamorphism/deformation and are thus considered to be isochemical.

Figure 7 displays Harker variation diagrams for the rocks of the BVS sequence. Here the major oxide wt\% has been plotted against $\mathrm{SiO}_{2}$ wt\% in order to understand the evolution of magma through element partitioning. Significant linear relationships have been observed among the basalts, andesites and granites for most of the major oxides. On the contrary, the rhyolite lacks such linear relationships with the other rock types.

Negative correlation of $\mathrm{SiO}_{2}$ with $\mathrm{CaO}, \mathrm{Fe}_{2} \mathrm{O}_{3}$, $\mathrm{MnO}$ and $\mathrm{TiO}_{2}$ exists for the basalt, andesite, and granite samples indicating fractionation of plagioclase, clinopyroxene, and ilmenite. A weak positive correlation is observed between $\mathrm{Na}_{2} \mathrm{O}$ and $\mathrm{SiO}_{2}$ for these samples. Scattering of data plots of $\mathrm{SiO}_{2}$ with $\mathrm{Al}_{2} \mathrm{O}_{3}, \mathrm{P}_{2} \mathrm{O}_{5}$, and $\mathrm{K}_{2} \mathrm{O}$ probably indicate the mobile nature of these elements during post-crystallization processes. Harker plots show that most of the major oxides have not been affected by the post-crystallization secondary processes.

The volcanic rocks of the BVS sequence were classified based on the total alkali versus silica
(TAS) plot with subdivisions after Middlemost (1994) (figure 8). On this classification scheme, five samples (R01, R12, R16, R17, and RJ25C) plot in the basalt field, four samples (RJ22A, RJ05, RJ24, and R04) plot in the fields of basaltic trachy-andesite and basaltic andesite, three samples (R03, RJ23C, and RJ25A) plot on the rhyolite field, and one sample (R07), which is a tuff, plots in the trachy-andesite field. In the QAP diagram (figure 9), the felsic samples plot in the granite field. Molar A/CNK for the granites ranges between 1.04 and1.12, suggesting weak peraluminous character of these rocks (figure 10).

In the AFM plot of Irvine and Baragar (1971) (figure 11), the basalts display tholeiitic trend. The other rock types like rhyolite, andesite, and granite show calc-alkaline affinities consistent with their generation in an island arc, subduction related setting.

In the $\mathrm{CaO} / \mathrm{Na}_{2} \mathrm{O}$ vs. $\mathrm{Al}_{2} \mathrm{O}_{3} / \mathrm{TiO}_{2}$ diagram (figure 12a), the granites of the study area plot on the mixing line between the pelite and basalt derived melts. The $\mathrm{Rb} / \mathrm{Sr} v s$. Rb/Ba plot (figure 12b) indicates that the granites formed from a plagioclaserich and clay-poor source. Moreover, high $\mathrm{Al}_{2} \mathrm{O}_{3} /$ $\mathrm{TiO}_{2}$ ratios point to the fact that they were generated at a higher temperature and pressure regime. The metapelitic derived melts generally have higher $\mathrm{Al}_{2} \mathrm{O}_{3} /(\mathrm{MgO}+\mathrm{FeO}(\mathrm{t}))$ and lower $\mathrm{CaO} /$ $(\mathrm{MgO}+\mathrm{FeO}(\mathrm{t}))$ ratios than those derived from meta-igneous rocks. The granites of the study area have $\mathrm{Al}_{2} \mathrm{O}_{3} /(\mathrm{FeO}(\mathrm{t})+\mathrm{MgO})<2$, suggesting metabasaltic and metatonalitic derived melts for these rocks.

\subsubsection{Trace and rare earth elements}

Basalt: Rare earth element (REE) data for the five basalt samples are documented in table 4 and the chondrite-normalized REE diagram for these samples is displayed in figure 13(a).

Chondrite-normalized REE trends for basalts can be clubbed into two groups; one with moderate enrichment in LREE relative to HREE and no negative $\mathrm{Eu}$ anomaly $\left(\mathrm{Eu} / \mathrm{Eu}^{*}=0.87-1.06\right)$ and the other with a relatively less enrichment of LREE in comparison to HREE with positive Eu anomaly $\left(\mathrm{Eu} / \mathrm{Eu}^{*}=1.44-1.49\right)$ indicating plagioclase accumulation. The subparallel REE patterns for the basalts suggest that the crystal fractionation is dominant in the evolution of the compositional variations, with plagioclase being a dominant fractionate. However, the possibility of varying degrees of partial melting cannot be ruled out for the samples.

Primitive mantle normalized trace element abundance patterns for the basalt samples show enrichments in large ion lithophile elements (LILE) 

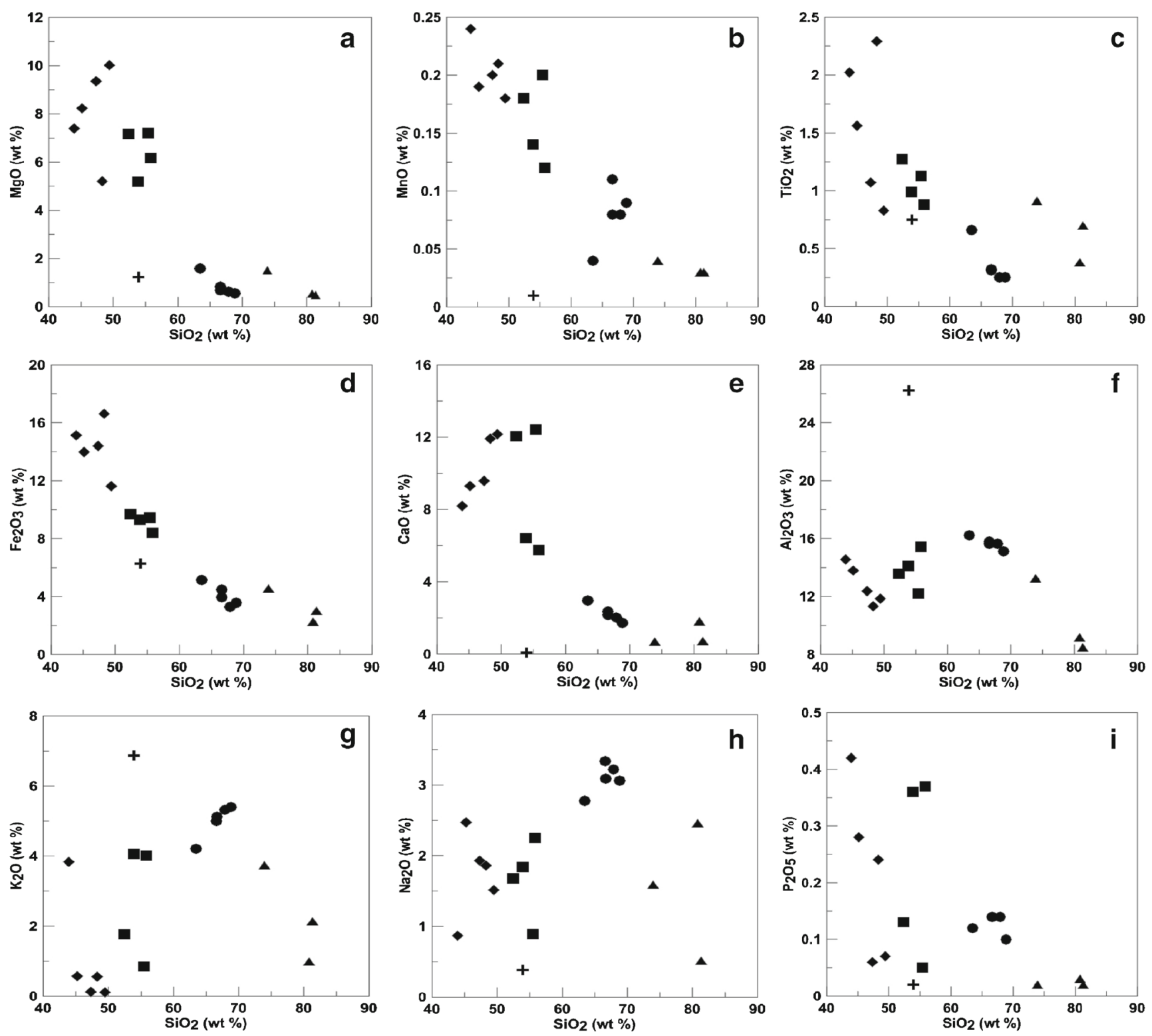

Figure 7. Harker plot showing the variation of major oxides as a function of $\mathrm{SiO}_{2}$ content for basalt, andesite, rhyolite, granite and tuff of BVS sequence.

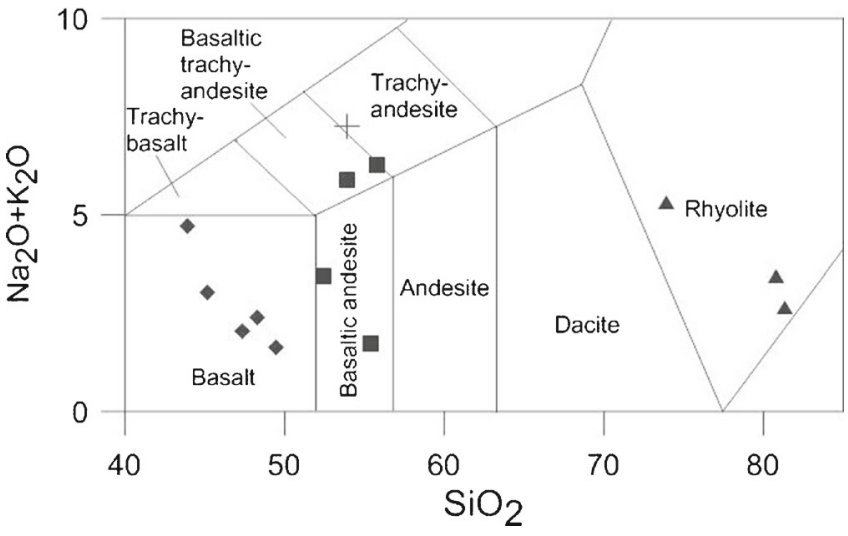

Figure 8. Total alkalis vs. silica diagram with subdivisions from after Middlemost (1994) showing the volcanic rock classification of the samples from BVS sequence. and $\mathrm{Pb}$ compared with high field strength elements (HFSE) (figure 13b). An overall trend of HFSE depletion and LILE enrichment is a characteristic subduction signature. An island arc setting is further corroborated by the depletion of $\mathrm{Nb}$ and $\mathrm{Ti}$.

The sample RJ25C shows a distinctive pattern from the rest of the four basalt samples. It shows marked negative anomalies for $\mathrm{Sr}, \mathrm{Th}, \mathrm{Nb}$, and $\mathrm{Zr}$ and positive anomalies for $\mathrm{K}$ and $\mathrm{Pb}$. The negative $\mathrm{Sr}$ anomaly is thought to be caused by plagioclase fractionation while negative $\mathrm{Th}$ and $\mathrm{Zr}$ anomalies may be related to fractionation of minor phases like zircon and/or allanite. Moreover, the observed positive anomaly for $\mathrm{K}$ may be attributed to K-feldspar accumulation. 


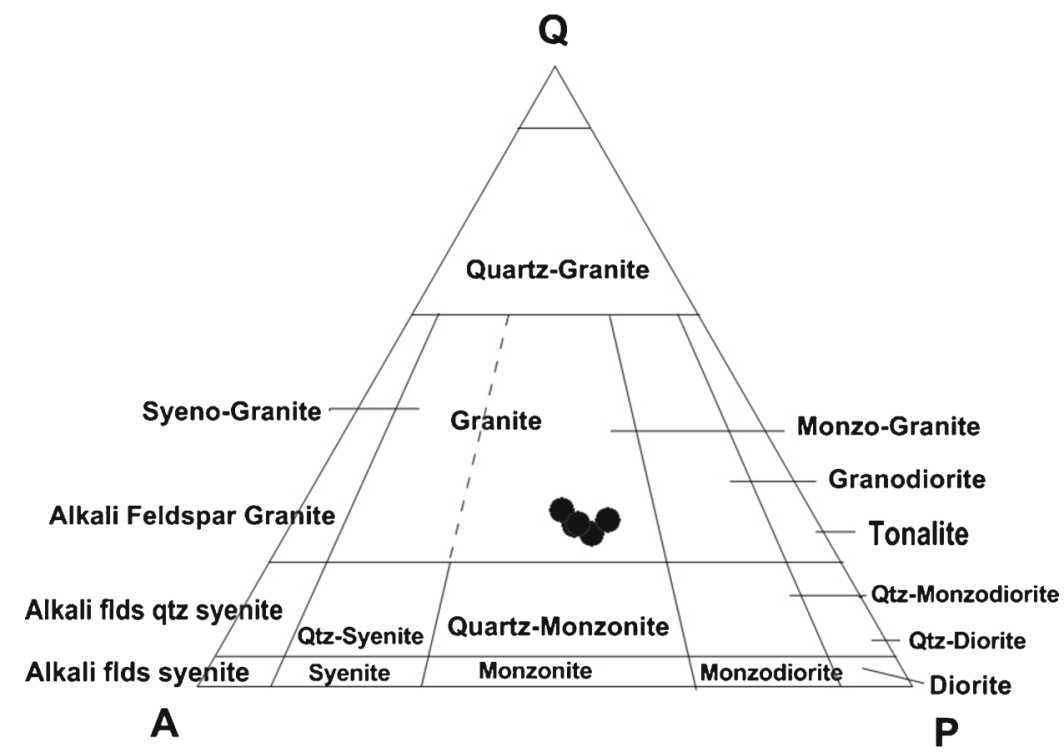

Figure 9. QAP plot (after Le Maitre et al. 1989) showing the felsic rocks of the BVS sequence all falling on the granite field.

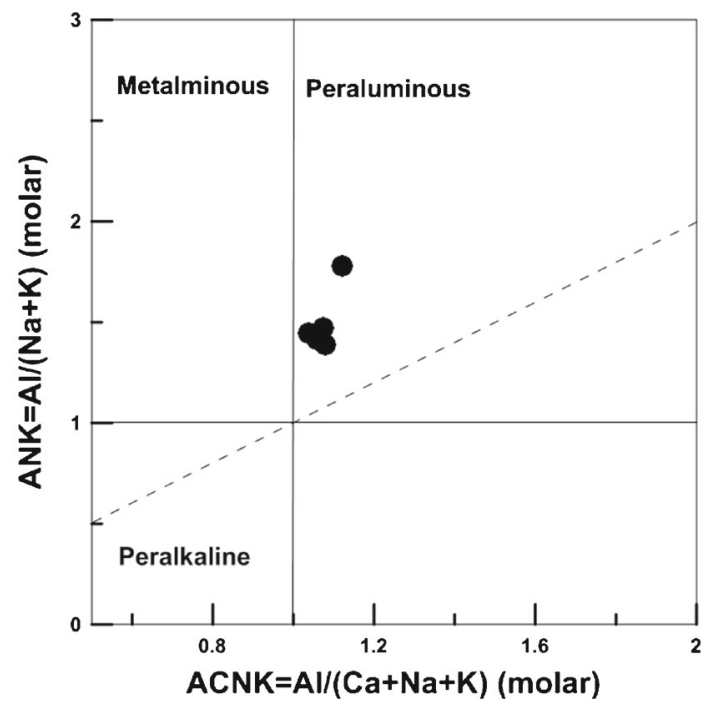

Figure 10. Variation of $\mathrm{Al} /(\mathrm{Na}+\mathrm{K})$ vs. $\mathrm{Al} /(\mathrm{Ca}+\mathrm{Na}+\mathrm{K})$ with fields (after Maniar and Piccoli 1989; Pearce et al. 1984) with divisions based on Shand index (1943) showing the peraluminous nature of the granites of BVS sequence.

The remaining four samples (R01, R12, R16, and R17) are characterized by marked positive anomalies for $\mathrm{Th}$ and $\mathrm{Pb}$ indicating crustal involvement in their evolution. Samples R12 and R16 show positive $\mathrm{Sr}$ and $\mathrm{Eu}$ anomalies showing plagioclase accumulation. No such anomalies are observed in samples R01 and R17.

Andesite: On the chondrite normalized REE diagram (figure 13c), the andesitic samples show moderate to strongly fractionated REE patterns characterized by a relatively enriched LREE and nearly flat HREE $\left(\mathrm{La}_{N} / \mathrm{Yb}_{N}=2.56-10.84\right.$, $\left.\mathrm{La}_{N} / \mathrm{Sm}_{N}=1.46-3.49, \mathrm{Gd}_{N} / \mathrm{Yb}_{N}=1.43-2.19\right)$. The andesitic samples are characterized by variable

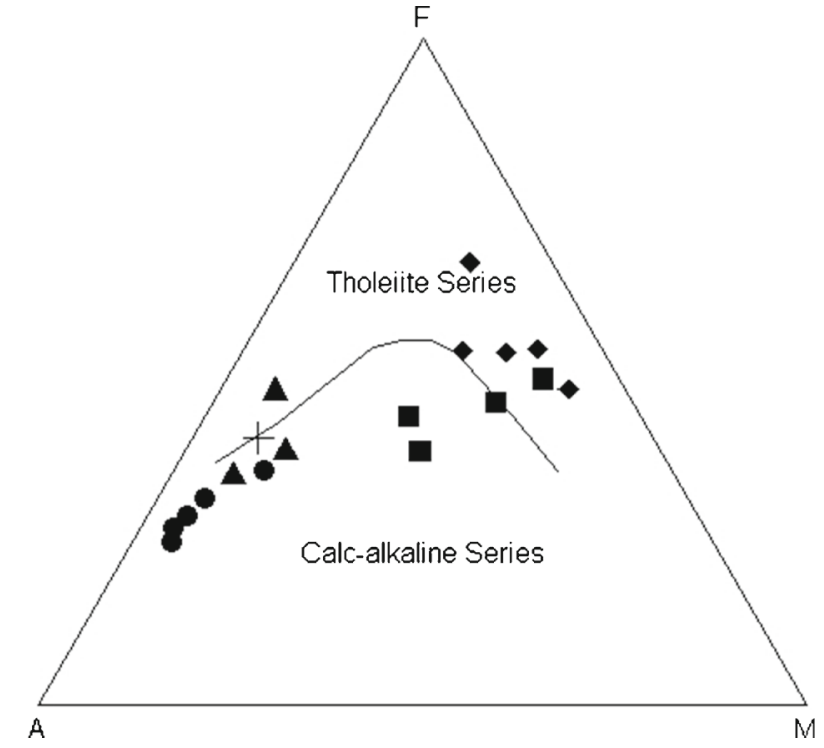

Figure 11. AFM diagram after Irvine and Baragar (1971) used for deciphering nature of magma for rocks of BVS sequence.

$\mathrm{Eu}$ anomalies $\left(\mathrm{Eu} / \mathrm{Eu}^{*}=0.4-1.28\right)$. The less fractionated samples (RJ22A, RJ05) show slightly positive to no $\mathrm{Eu}$ anomalies. While the more fractionated samples (R04, RJ24) are characterized by negative Eu anomalies.

On the primitive mantle normalized spider diagram (figure 13d), the andesitic samples show moderate to highly fractionated patterns characterized by $\mathrm{Nb}$ depletion and $\mathrm{Pb}$ enrichment. The relatively more fractionated samples (R04, RJ24) are characterized by negative anomalies for $\mathrm{Ba}, \mathrm{Sr}, \mathrm{Eu}$, and $\mathrm{Ti}$ indicating feldspar and ilmenite fractionation. The observed negative $\mathrm{Ba}$ anomaly may also be attributed to biotite and/or hornblende 

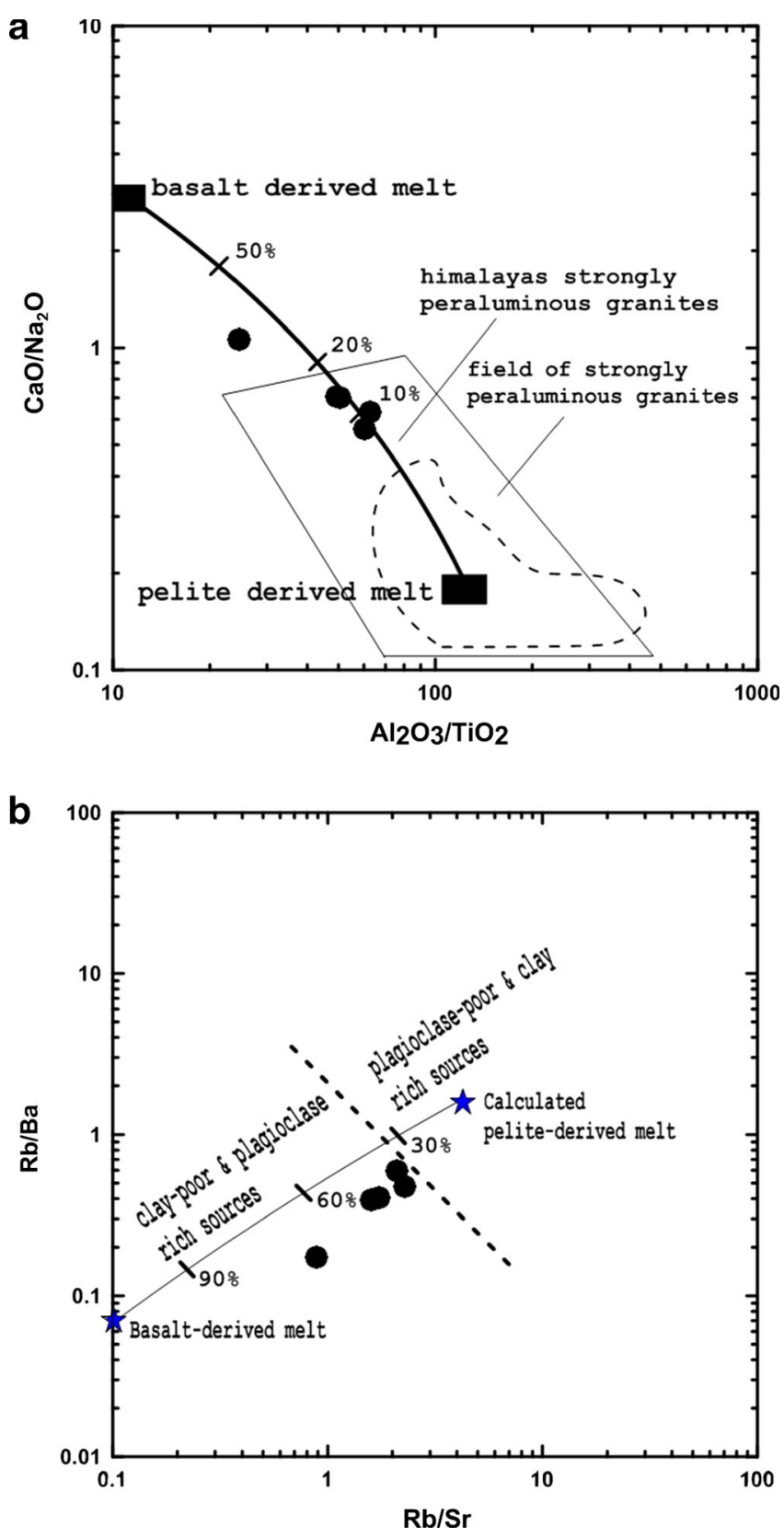

Figure 12. (a) $\mathrm{CaO} / \mathrm{Na}_{2} \mathrm{O}-\mathrm{Al}_{2} \mathrm{O}_{3} / \mathrm{TiO}_{2}$ plot after Sylvester (1998) showing the composition of the source for generation of the granites of BVS sequence. (b) $\mathrm{Rb} / \mathrm{Sr}$ vs. $\mathrm{Rb} / \mathrm{Ba}$ plot after Patino-Dounce and Harris (1998) constraining the granite forming melt to be of clay poor and plagioclase rich composition.

fractionation. The observed negative $\mathrm{Nb}$ anomaly in the andesitic samples may have been caused by ilmenite fractionation.

Rhyolite and Tuff: On the chondrite-normalized REE diagram (figure 13e), all the calc-alkaline rhyolite together with the tuff samples are characterized by a strongly fractionated REE pattern $\left(\mathrm{La}_{N} / \mathrm{Yb}_{N}=9.05-13.59\right)$, a fractionated LREE $\left(\mathrm{La}_{N} / \mathrm{Sm}_{N}=3.42-4.96\right)$ pattern, flat to negative Eu anomalies $\left(\mathrm{Eu} / \mathrm{Eu}^{*}=0.44-0.96\right)$, and flat HR-EE distribution patterns $\left(\mathrm{Gd}_{N} / \mathrm{Yb}_{N}=1.32-1.92\right)$.
On primitive mantle normalized trace element abundance diagram (figure 13f), the rhyolite and the tuff samples exhibit strongly negative $\mathrm{Nb}, \mathrm{Sr}$, $\mathrm{Eu}$ and $\mathrm{P}$ anomalies and positive $\mathrm{Pb}$ anomaly. The negative $\mathrm{Sr}, \mathrm{Eu}$ and $\mathrm{P}$ anomalies may be explained by the plagioclase and apatite fractionation, either in the solid residuum left by partial melting or fractional crystallization. The negative $\mathrm{Nb}$ anomaly together with the positive $\mathrm{Pb}$ anomaly is indicative of crustal signature.

Granite: The rare earth element (REE) trends (figure 13g) confirm that the granite samples have REE enriched patterns $\left(\mathrm{La}_{N} / \mathrm{Yb}_{N}=12.22-71.11\right)$, a fractionated LREE $\left(\mathrm{La}_{N} / \mathrm{Sm}_{N}=4.60-7.37\right)$ pattern, negative $\mathrm{Eu}$ anomalies $\left(\mathrm{Eu} / \mathrm{Eu}^{*}=0.32-0.46\right)$, nearly flat HREE distribution patterns and depletion of MREE relative to the HREE $\left(\mathrm{Gd}_{N} / \mathrm{Yb}_{N}=\right.$ $1.47-7.44)$. The depletion of the MREE relative to the HREE reflects fractionation of hornblende and/or clinopyroxene during petrogenesis whereas the negative $\mathrm{Eu}$ anomaly indicates plagioclase fractionation.

The primitive mantle normalized trace element variation trends (figure 13h) depict large ion lithophile elements (LILE) enriched pattern and negative anomalies for $\mathrm{Ba}$ and $\mathrm{Sr}$. There is also significant depletion of three high field strength elements (HFSE) involving $\mathrm{Nb}, \mathrm{P}$, and $\mathrm{Ti}$, with $\mathrm{Zr}$ showing slight negative anomaly. The observed $\mathrm{Ba}$ negative anomaly may be either due to alteration or fractionation of K-feldspar, hornblende and/or biotite during genesis of these rocks as Ba substitutes for K in K-feldspar, hornblende, and biotite. Similarly, Sr concentration may be influenced by the plagioclase fractionation. The normalized plot also shows negative anomalies for $\mathrm{P}, \mathrm{Ti}$ and $\mathrm{Zr}$ which may suggest early fractionation of apatite, zircon, and Ti-bearing phases like titanite, rutile and ilmenite. The negative anomaly for $\mathrm{Nb}$ may be attributed to crustal signature or a subduction environment. In the subduction zone tectonic settings or in an island arc environment, due to the presence of fluid, entire $\mathrm{Nb}$ tends to go into $\mathrm{Ti}$ bearing phases like titanite, rutile and ilmenite. In our samples, negative $\mathrm{Nb}$ anomaly is probably due to its fractionation into Ti-bearing phases.

\subsubsection{Geotectonic classification of the rocks}

On the $\mathrm{Th} / \mathrm{Yb}$ vs. Nb/Yb plot after Pearce (2008), the basalts clearly show a volcanic arc setting of eruption (figure 14a). This suggests a subduction zone environment for their formation. In the tectonic discrimination $\mathrm{Nb}-\mathrm{Y}$ plot of Pearce et al. (1984) the granite samples show slight affinity towards VAG and Syn-COLG (figure 14b) suggesting volcanic arc setting. 

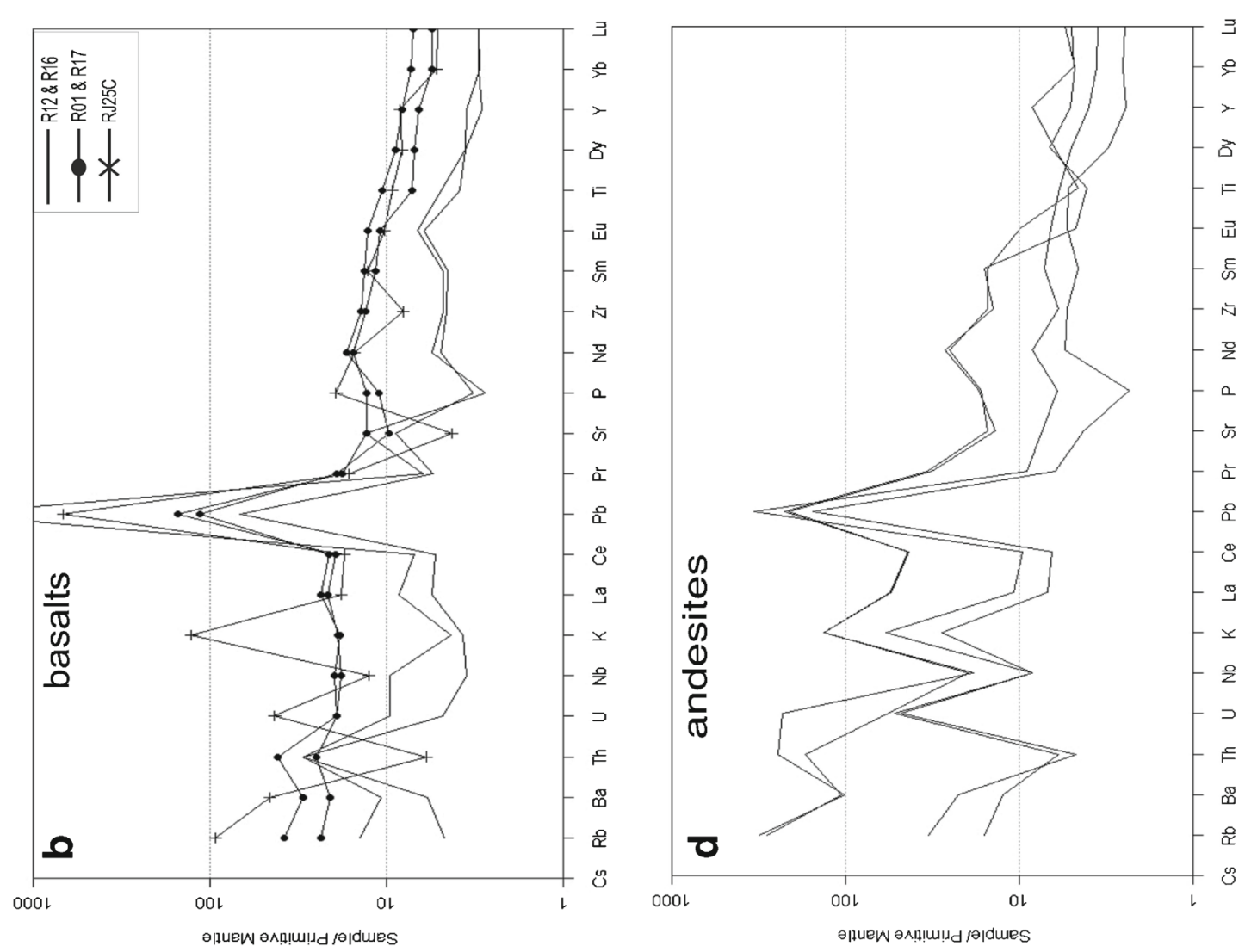

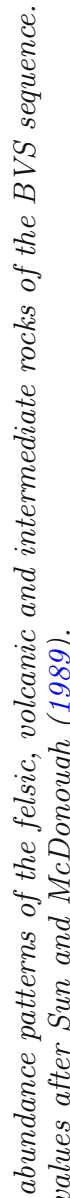
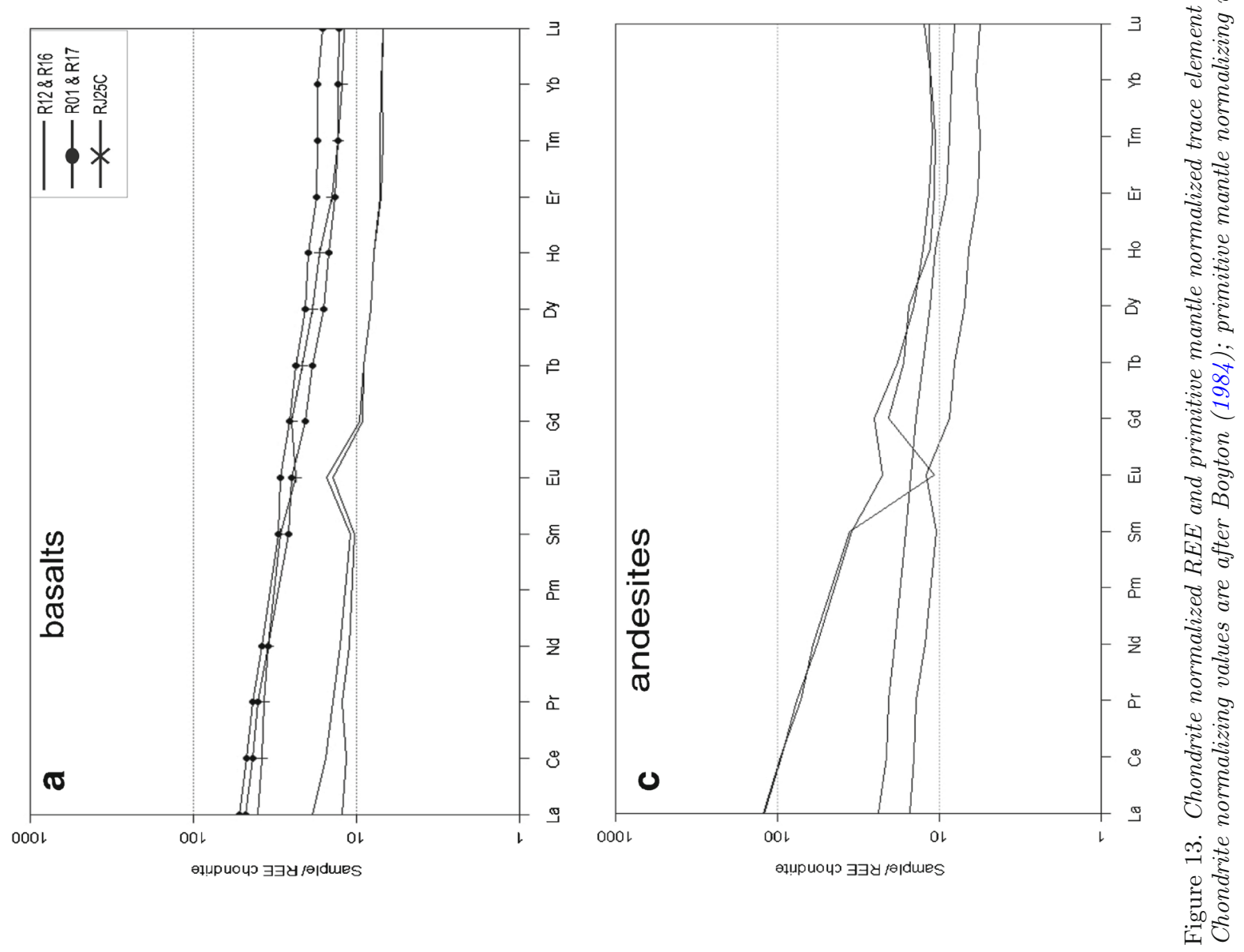

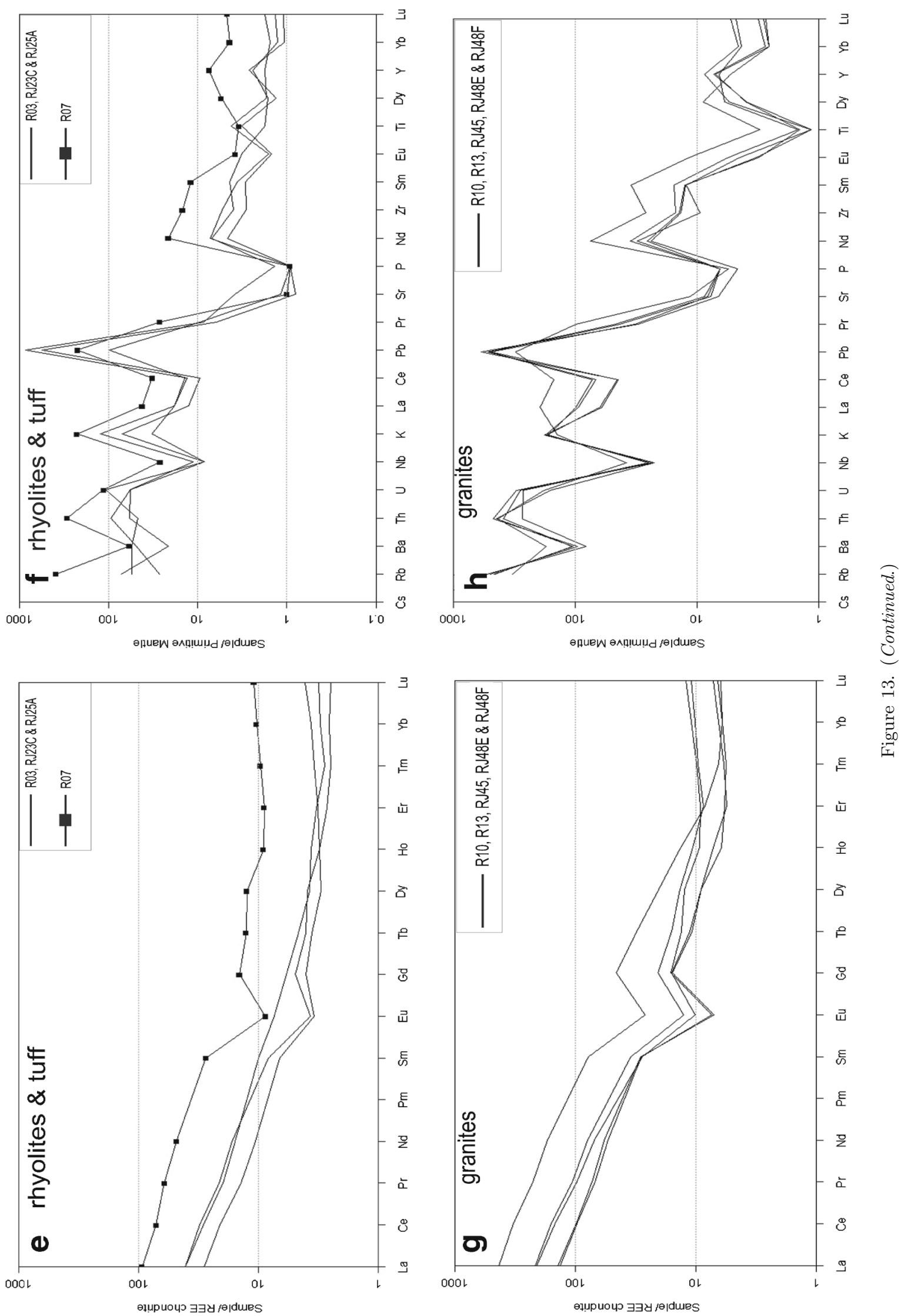

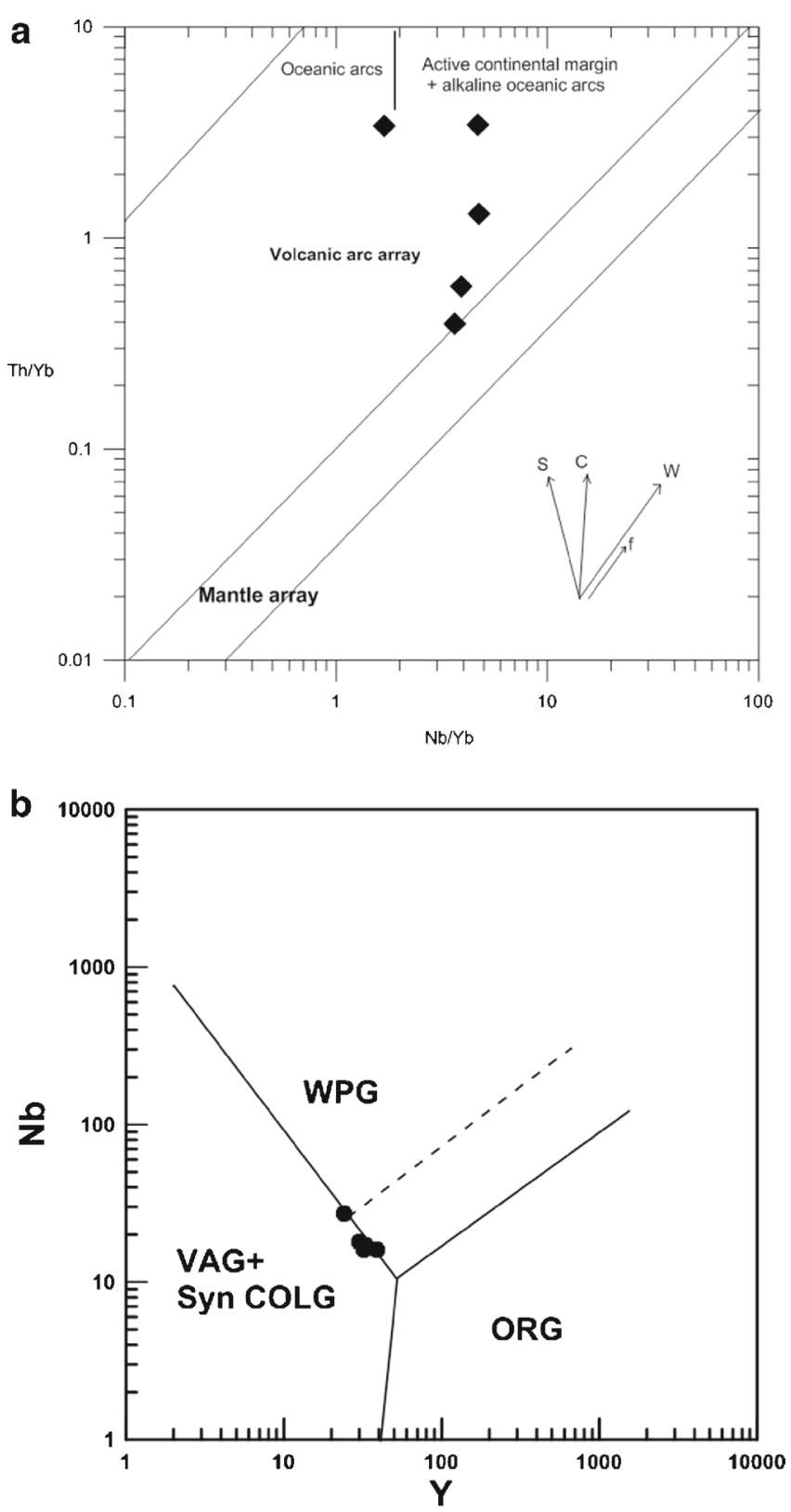

Figure 14. (a) Plot of Th/Yb vs. Nb/Yb after Pearce (2008) for the basalts of BVS sequence points towards a volcanic arc setting for the tectonic environment of their eruption. The mantle array extends from mid-ocean ridge basalts (MORB) to within-plate ocean island basalts (OIB). TH, CA, and SHO are respectively fields for tholeiitic, calc-alkaline, and shoshonitic basaltic rocks from convergent margins. S, C, $\mathrm{W}$, and $\mathrm{f}$ are vectors for subduction component, crustal contaminant component, within plate processes, and fractional crystallization respectively. (b) Nb vs. Y tectonic discrimination diagram (after Pearce et al. 1984) for the granites show their tectonic origin to be of volcanic arc setting. Field labels: Volcanic Arc Granite (VAG), Within Plate Granite (WPG), Ocean Ridge Granite (ORG), Syn-collision Granite (Syn-COLG).

\section{Concluding remarks}

Emplacement of diverse felsic and mafic rocks in the BVS sequence together probably testifies for a multi-stage and multi-source magmatism for the area in an island arc setting. The presence of pillow basalt suggests that the volcanic eruption was under shallow marine/subaqueous environment. Mafic pyroclasts and tuffs are formed by intermittent explosive eruptions of basic and acidic magmas respectively. Presence of hybrid rocks like basaltic andesite and andesite, and phenomenon of mixing and mingling supported by structures and textures in the volcanic rocks suggest that the two magmas, mafic and felsic, co-existed for sufficient time before eruption. Tholeiitic trend for basalt and calc-alkaline affinities of andesite, rhyolite, and granite indicate their generation in an island arc, subduction related setting. In the $\mathrm{Nb} / \mathrm{Yb}$ vs. $\mathrm{Th} / \mathrm{Yb}$ discrimination diagram, basalts plot in the alkaline oceanic arc array suggesting their generation in the subduction zone. Granites show affinity towards VAG and Syn-COLG. HFSE depletion and LILE enrichment of the basalts is also a characteristic of subduction zone environment. Island arc setting is further corroborated by depletion of $\mathrm{Nb}$ and $\mathrm{Ti} . \mathrm{Al}_{2} \mathrm{O}_{3} / \mathrm{TiO}_{2}$ vs. $\mathrm{CaO} / \mathrm{Na}_{2} \mathrm{O}$ and $\mathrm{Rb} / \mathrm{Sr}$ vs. $\mathrm{Rb} / \mathrm{Ba}$ plots denote granitic magma generation from plagioclase rich and clay poor metabasalt and metatonalite protolith. Low grade of metamorphism probably to greenschist facies condition is indicated by the presence of secondary amphibole and chlorite in basalt. However, well preserved igneous texture in basalt and rhyolite undoubtedly restricts the metamorphic effect to low grade only. Low grade metamorphism of volcano-sedimentary sequence along with the pervasive subsurface mafic-ultramafic bodies is characteristic of greenstone belt. This low grade metamorphosed volcano-sedimentary sequence may be correlated with extension of Mahakoshalfolded mobile belt of central India, presently situated between north and south Son-Narmada faults.

It seems that various rock types of volcanic and volcano-sedimentary sequence and their associated rocks exposed in the Bathani area are manifestation of collision of northern and southern Indian blocks during Proterozoic period. The explosive submarine volcanism may be related to the culmination of the collision of the aforementioned blocks during Neoproterozoic (1.0 Ga) as the Grenvillian metamorphism is well established in various parts of CGGC. The granitoids around Gaya-Rajgir area, north CGGC of Central Indian Tectonic Zone (CITZ) might have originated at different times corresponding to collision of the north and the south Indian blocks.

\subsection{Plausible magmatic model}

Inferences from the field, petrological, mineral chemical and geochemical data allow us to propose 
a plausible magmatic model for the generation of the Bathani suite of rocks as discussed below. A schematic cartoon for the suggested model is shown in figure 15.

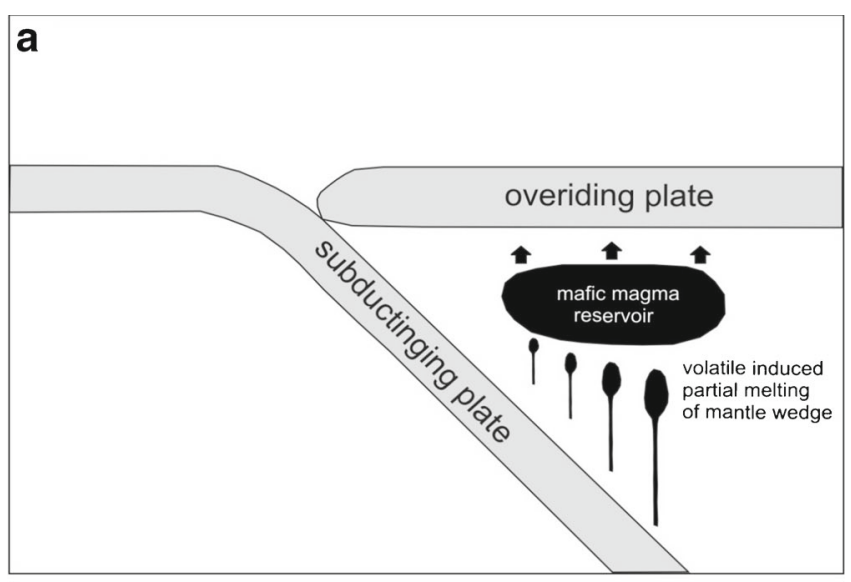

b
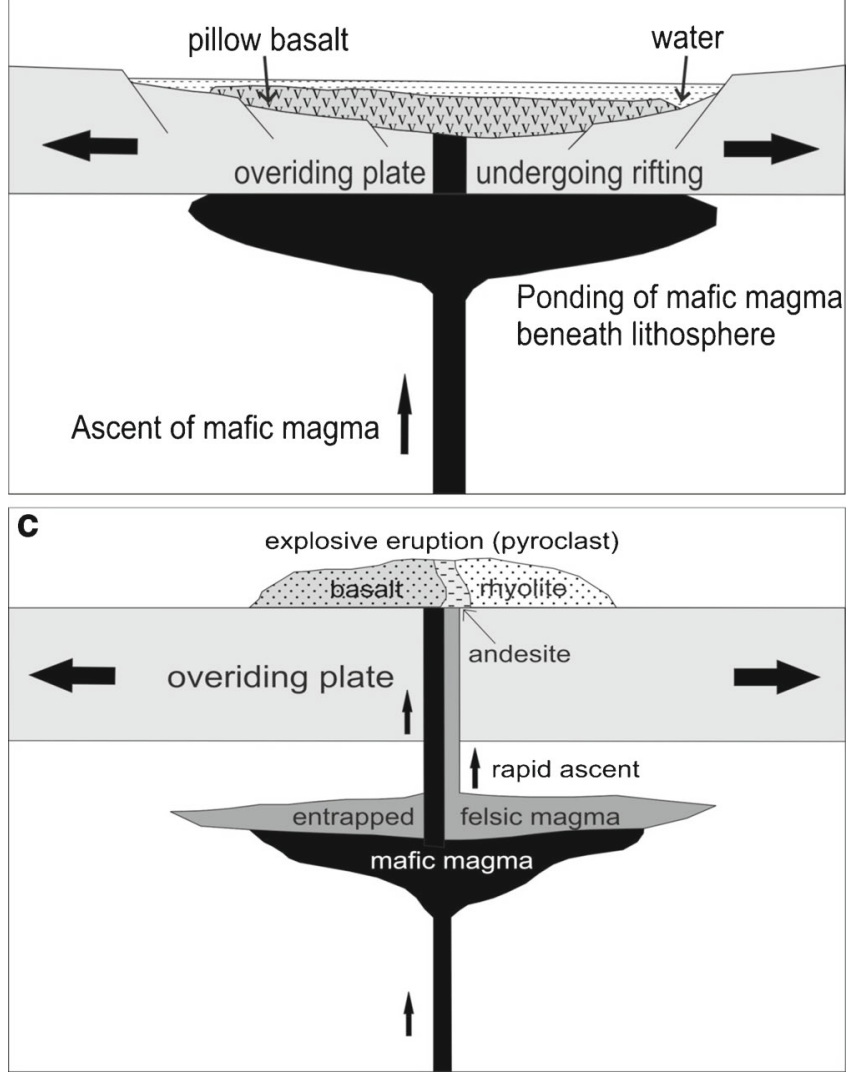

Figure 15. Schematic representation of the magma generation model suggested for the volcanics of the BVS sequence. (a) Generation of mafic magma in an arc environment due to volatile induced partial melting of the subducting slab. (b) Lithospheric thinning, subsidence and rifting by underplating of mafic magma beneath lithospheric slab. Effusive eruption of mafic magma occurred through the rifts forming pillow basalts. (c) Interception of mafic magma by preexisting felsic rhyolitic sill resulting in hybrid andesitic rocks due to mixing of the magmas. Volcanic eruptions ensued resulting in intermittent eruption of rhyolitic and basaltic magmas along with mafic pyroclasts.
Mafic magmas are probably generated by volatile-induced partial melting of the mantle wedge in a subduction zone setting. The mafic magmas then ascended as a network of dykes. During their ascent, mafic magma pooled and underplated the lithosphere and got entrapped and may also have formed dyke swarms of mafic-ultramafic composition. The probability of subsurface intrusive basic igneous rocks was highlighted by the Bouger gravity anomaly map (Das and Patel 1984) representing anomalous NE-SW trending gravity high to the north of Bodh Gaya. Such kind of magma entrapment is known to cause thermal erosion at the base of the lithosphere. Thinning of the lithosphere by thermal erosion gave way to lithospheric subsidence and subsequently to the formation of sedimentary basin. Accumulation of sediments developed rift system in the basin through which effusive eruption of basalt forming pillows occurred.

However, the rhyolitic magma was originally derived from some deeper zones totally unrelated to the basaltic magmatism. The ascending rhyolitic magma may have got accumulated in sill-like isolated chambers and shortly before eruption, were intruded by the ascending mafic magma. Interaction of the hotter, volatile-rich mafic magma with the rhyolitic magma reduced the rhyolite magma viscosity, thereby triggering rhyolitic volcanism. The intermediate tuffs may possibly have formed due to explosive eruption in the same environment. Presence of hybrid rocks like andesite and basaltic andesite suggests that the two magmas, mafic and felsic, interacted for sufficient time for mixing to take place. Later on, both the magmas erupted simultaneously as evidenced by the presence of rhyolite clasts in basaltic flows. Granitic plutonism succeeded this event and is the result of fractional crystallization of mafic magma.

In the given scenario we can infer that the basaltic extrusions ascended through a laterally extensive subsurface dyke system. Pillow basalts erupted via sutures developed due to rifting developed by lithospheric subsidence while some basic magma was intercepted by an already existent rhyolite magma chamber causing magma mixing and mingling and then finally making their way to the surface as volcanic eruptions.

\section{Acknowledgements}

Ashima Saikia acknowledges the CSIR grant vide Project no. 24(0317)/12/EMR-II. Authors extend their gratitude to the anonymous reviewers for their suggestions, which have improved the manuscript their considerably. 


\section{References}

Ahmad M and Wanjari N 2009 Volcano-sedimentary sequence in the Munger-Rajgir metasedimentary belt, Gaya district, Bihar; Indian J. Geosci. 63(4) 351-360.

Ahmad M and Dubey J 2011 Report on prospecting for gold and silver mineralization in Munger Rajgir group of rocks in Nalanda district, Bihar; P(ii), Unpublished report, GSI (F.S.: 2008-09, 2009-10, 2011-12).

Ahmad M and Paul A Q 2012 Tectono-stratigraphic constraints of the Bathani volcano-sedimentary, volcanic sequences and associated rocks, Chotanagpur granite gneiss complex, Gaya district, Bihar; NEWS Geol. Surv. India, Eastern region 33(1\&2) 13-15.

Ahmad M and Paul A Q 2013 Investigation of volcanosedimentary sequence and associated rocks to identify gold and base metal mineralization at Gere-Kewti area of Gaya district, Bihar (G4), Unpublished report, GSI (F.S.: 2012-13).

Balaram V, Saxena V K, Manikyamba C and Ramesh S L 1990 Determination of rare earth elements in Japanese rock standards by inductively coupled plasma mass spectrometry; At. Spectrosc. 11(1) 19-23.

Banerji A K 1991 Presidential address: Geology of the Chotanagpur region; Indian J. Geol. 63 275-282.

Boyton W V 1984 Cosmochemistry of the rare earth elements: Meteorite studies; In: Rare Earth Element Geochemistry (ed.) Henderson P (Amsterdam: Elsevier), pp. 63-114.

Cawthorn R G and Collerson K D 1974 The recalculation of pyroxene end-member parameters and the estimation of ferrous and ferric iron content from EPMA; Am. Mineral. 59 1203-1208.

Chatterjee N and Ghosh N C 2011 Extensive Early Neoproterozoic high-grade metamorphism in North Chotanagpur Gneissic Complex of the Central Indian Tectonic Zone; Gondwana Res. 20 362-379.

Chatterjee N, Crowley J I and Ghose N C 2008 Geochronology of the $1.55 \mathrm{Ga}$ Bengal anorthosite and Grenvillian metamorphism in the Chotanagpur Gneissic Complex, eastern India; Precamb. Res. 161 303-316.

Chatterjee N, Banerjee M, Bhattacharya A and Maji A K 2010 Monazite chronology, metamorphism-anatexis and tectonic relevance of the mid-Neoproterozoic Eastern Indian Tectonic Zone; Precamb. Res. 179 99-120.

Das B 1967 On the lithological sequence and overall structure of the rocks around Rajgir, Bihar; Bull. Geol. Soc. India 4(2) 46-49.

Das B and Patel N P 1984 Nature of the Narmada-Son lineament; J. Geol. Soc. India 25 267-276.

Deer W A, Howie R A and Zussman J 1992 An introduction to the rock forming minerals; ELBS Publication, UK, $696 \mathrm{p}$.

Droop G T R 1987 A general equation for estimating $\mathrm{Fe}^{3+}$ concentrations in ferromagneisan silicates and oxides from microprobe analyses using stoichiometric criteria; Min. Mag. 51 431-435.

Fleet M E and Barnett R L $1978 \mathrm{Al}^{\mathrm{iv}} / \mathrm{Al}^{\mathrm{vi}}$ portioning in calciferous amphiboles from the frood mine, Sudbury, Ontario; Can. Miner. 16 527-532.

Ghose N C 1983 Geology, tectonics and evolution of the Chhotanagpur granite gneiss complex, eastern India; In: Structure and Tectonics of Precambrian Rocks of India, Recent Researches in Geology 10 (ed.) Sinha-Roy S (Delhi: Hindustan Publishing Corporation), pp. 211247.

Ghose N C and Mukherjee D 2000 Chotanagpur gneissgranulite complex, eastern India - a kaleidoscope of global events; In: Geology and Mineral Resources of Bihar and Jharkhand (eds) Trivedi A N, Sarkar B C, Ghose N C and Dhar Y R, Platinum Jubilee Commemoration Volume, Indian School of Mines, Dhanbad, Monograph 2. Institute of Geoexploration and Environment, Patna, pp. 33-58.

Goswami P K, Pant C C and Pandey S 2009 Tectonic controls on the geomorphic evolution of alluvial fans in the Piedmont Zone of Ganga Plain, Uttarakhand, India; J. Earth Syst. Sci. 118(3) 245-259.

GSI 1998 Acharyya S K, Dasgupta A and Chakravorty K (eds), Geological map of India, 7th edn, Geological Survey of India, Hyderabad.

GSI 2000 Eastern Nepal Himalaya and Indo-Gangetic Plains of Bihar; In: Seismotectonics Atlas of India and its Environs (eds) Narula P L, Acharyya S K and Banerjee J, Geol. Surv. India, pp. 26-27.

Irvine T N and Baragar W R A 1971 A guide to the geochemical classification of the common volcanic rocks; Can. J. Earth Sci. 8 523-548.

Karmakar S, Bose S, Basu Sarbadhikari A and Das K 2011 Evolution of granulite enclaves and associated gneisses from Purulia, Chhotanagpur Granite Gneiss Complex, India: Evidence for 990-940 Ma tectonothermal event(s) at the eastern India cratonic fringe zone; J. Asian Earth Sci. 41(1) 69-88.

Le Maitre R W, Bateman P, Dudek A, Keller J, Lameyre J, Le Bas M J, Sabine P A, Schmid R, Sorensen H, Streckeisen A, Woolley A R and Zanettin B 1989 A Classification of Igneous Rocks and Glossary of Terms; Recommendations of the International Union of Geological Sciences Subcommission on the Systematics of Igneous Rocks, Oxford: Blackwell Scientific.

Leake B E, Woolley A R, Arps C E S, Birch W D, Gilbert M C, Grice J D, Howthorne F C, Kato A, Kisch H J, Krivovichev V G, Linthout K, Laird J and Mandarino T 1997 Nomenclature of amphiboles. Report of the subcommittee on amphiboles of the International Mineralogical Association: Commission on new mineral names; Min. Mag. 61 295-321.

Mahadevan T M 2002 Geology of Bihar and Jharkhand; Geological Society of India, Bangalore, 563p.

Maji A K, Goon S, Bhattacharya A, Mishra B, Mahato S and Bernhardt H J 2008 Proterozoic polyphase metamorphism in the Chotanagpur Gneiss Complex (India), and implications for trans-continental Gondwana correlation; Precamb. Res. 162 385-402.

Mallick A K 1993 Dating of granite plutons in Bihar mica belt, Bihar; Rec. Geol. Surv. India 126(2) 27-29.

Maniar P D and Piccoli P M 1989 Tectonic discrimination of granitoids; GSA Bull. 101 635-643.

Mazumdar S K 1988 Crustal evolution of the Chhotanagpur gneissic complex and the mica belt of Bihar; In: Precambrian of the Eastern Indian shield (ed.) Mukhopadhyay D, Geol. Surv. India Memoir 8 49-83.

Middlemost E A K 1994 Naming materials in the magma/ igneous system; Earth Sci. Rev. 37 215-224.

Mukherjee D and Ghose N C 1998 Conglomerate at the base of Bihar Mica Belt metasediments, Koderma district, Bihar and its stratigraphic significance; National Seminar on Advancement of Geological Sciences in Bihar, Geological Survey of India, Patna, pp. 15-16.

Mukhopadhyay P K, Ray S, Saran R R and Huin A K 2011 A status report on the geology, structure, metamorphism, petrology, mineral chemistry, petrochemistry, geochemistry and geochronology and economic potentiality of the major units of Chhotanagpur Gneissic Complex in West Bengal, Jharkhand and Bihar, eastern India (SER/ER/HQ/2008/013), Unpublished report, GSI (F.S.: 2008-09, 2009-10). 
Patino-Dounce A E and Harris N 1998 Experimental constraints on Himalayan anatexis; J. Petrol. 39(4) 689-710.

Pearce J A, Harris B W and Tindle A G 1984 Trace element discrimination diagrams for the tectonic interpretation of granitic rocks; J. Petrol. 25 956-983.

Pearce J A 2008 Geochemical fingerprinting of oceanic basalts with applications to ophiolite classification and the search for Archean oceanic crust; Lithos 100 14-48.

Pouchou J L and Pichoir F 1987 Basic expressions of PAP computation for quantitative EPMA, Proceedings of ICXOM 11, Ontario, pp. 249-253.

Purohit K K, Mukherjee P K, Saini N K, Khanna P P and Rathi M S 2006 Geochemical survey of stream sediments from upper parts of Alaknanda, Mandakini, Bhilangana and Bhagirathi catchments, Garhwal Himalaya; Him. Geol. 27(1) 31-39.

Raiverman V, Kunte S V and Mukherjee A 1983 Basin geometry, Cenozoic sedimentation and hydrocarbon prospects in northwestern Himalaya and Indo-Gangetic plains; In: Petroliferous Basins of India (ed.) Bhandari L L, Petroleum Asia Journal 6(4) 67-92.

Rao M B R 1973 The subsurface geology of the IndoGangetic plains; J. Geol. Soc. India 14(3) 217-242.

Saini N K, Mukherjee P K, Rathi M S, Khanna P P and Purohit K K 1998 A new geochemical reference sample of granite (DG-H) from Dalhousie, Himachal Himalaya; J. Geol. Soc. India 52 603-606.

Saini N K, Mukherjee P K, Rathi M S and Khanna P P 2000 Evaluation of energy-dispersive x-ray fluorescence spectrometry in the rapid analysis of silicate rocks using pressed powder pellets; X-Ray Spectrometry 29(2) 166-172.

Saini N K, Mukherjee P K, Khanna P P and Purohit K K 2007 A proposed amphibolite reference rock sample (AMH) from Himachal Pradesh; J. Geol. Soc. India 69 799-802.

Sanyal S and Sengupta P 2012 Metamorphic evolution of theChotangapur Granite Gneiss Complex of the East
Indian Shield: Current status; In: Paleoproterozoic of India Geological Society (eds) Mazumder R and Saha D, Geol. Soc. London Spec. Publ. 365 117-145.

Sastri V V, Bhandari L L, Raju A T R and Dutta A K 1971 Tectonic framework and subsurface stratigraphy of the Ganga basin; J. Geol. Soc. India 12 222-233.

Shand S J 1943 Eruptive rocks. Their Genesis, Composition, Classification, and their Relation to Ore Deposits; 3rd edn, John Wiley \& Sons, 488p.

Singh S P 1998 Precambrain stratigraphy of Bihar - an overview; In: The Indian Precambrian (ed.) Paliwal B S, Scientific Publishers India, Jodhpur, pp. 376-408.

Singh Y and Krishna V 2009 Rb-Sr geochronology and petrogenesis of granitoids from the Chotanagpur Granite Gneiss Complex of Raikera-Kunkuri region, central India; J. Geol. Soc. India 74 200-208.

Speer J A 1984 Micas in igneous rocks; In: Mineralogical Society of America; Rev. Mineral. 13 299-356.

Srivastava G S and Sengupta D K 1967 Structural evolution of the metasediments around Rajgir, Patna; Proc. National Institute of Science India 3(Suppl. 5A) 95-115.

Sun S S and McDonough W F 1989 Chemical and isotopic systematics of oceanic basalts: Implications for mantle composition and processes; In: Magmatism in Ocean Basins (eds) Saunders A D and Norry M J, Geol. Soc. London Spec. Publ. 42 313-345.

Sylvester P J 1998 Post-collisional strongly peraluminous granites; Lithos 4 529-44.

Valdiya K S 1976 Himalayan transverse faults and folds and their parallelism with subsurface structures of the northern Indian plains; Tectonophys. 32 353-386.

Wanjari N R, Chaturvedi R and Mahanta D N 2012 Specialised thematic mapping in Munger-Rajgir Group of rocks to examine structural and stratigraphic set up in and around Gaya-Rajgir areas in parts of Gaya, Nawada and Jahanabad districts of Bihar; Unpublished report, GSI (F.S.: 2008-09, 2009-10). 